NBER WORKING PAPER SERIES

\title{
THE EVOLUTION OF CORPORATE OWNERSHIP AFTER IPO: THE IMPACT OF INVESTOR PROTECTION
}

\author{
C. Fritz Foley \\ Robin Greenwood \\ Working Paper 14557 \\ http://www.nber.org/papers/w14557 \\ NATIONAL BUREAU OF ECONOMIC RESEARCH \\ 1050 Massachusetts Avenue \\ Cambridge, MA 02138 \\ December 2008
}

A previous version of this paper circulated as "The Evolution of Corporate Ownership: Evidence from 34 countries." We are grateful to David Blitzer at Standard and Poors for providing data, and Cliff Holderness, Andrew Metrick, and Karl Lins for sharing their data with us. Evie Spanos and Sonya Lai provided excellent research assistance. We thank Malcolm Baker, Mihir Desai, Cliff Holderness, Paul Gompers, Karl Lins, Randall Morck, Richard Ruback, David Scharfstein, Andrei Shleifer, Matt Spiegel, and seminar participants at the Darden International Finance Conference, Harvard, HKUST Business School, Singapore Management University, the University of Oregon, and the University of Texas at Austin for helpful comments. The Harvard Business School Division of Research provided funding for this study. The views expressed herein are those of the author(s) and do not necessarily reflect the views of the National Bureau of Economic Research.

NBER working papers are circulated for discussion and comment purposes. They have not been peerreviewed or been subject to the review by the NBER Board of Directors that accompanies official NBER publications.

(C) 2008 by C. Fritz Foley and Robin Greenwood. All rights reserved. Short sections of text, not to exceed two paragraphs, may be quoted without explicit permission provided that full credit, including (C) notice, is given to the source. 
The Evolution of Corporate Ownership After IPO: The Impact of Investor Protection

C. Fritz Foley and Robin Greenwood

NBER Working Paper No. 14557

December 2008

JEL No. G3,K22

\begin{abstract}
$\underline{\text { ABSTRACT }}$
Recent research documents that ownership concentration is higher in countries with weak investor protection. However, drawing on panel data on corporate ownership in 34 countries between 1995 and 2006, we show this pattern does not hold for newly public firms, which tend to have concentrated ownership regardless of the level of investor protection. We show that firms in countries with strong investor protection are more likely to experience decreases in ownership concentration after listing, that these decreases appear in response to growth opportunities, and that they are associated with new share issuance. We consider the implications of these findings for financing choices and patterns in firm growth and analyze alternative explanations for the diffusion of ownership that could distort our interpretations. We conclude that ownership concentration falls as firms age following their IPO in countries with strong investor protection because firms in these countries raise capital and grow, diluting blockholders in the process.
\end{abstract}

\author{
C. Fritz Foley \\ Harvard Business School \\ Soldiers Field \\ Boston, MA 02163 \\ and NBER \\ ffoley@hbs.edu \\ Robin Greenwood \\ Harvard Business School \\ Soldiers Field \\ Boston, MA 02163 \\ rgreenwood@hbs.edu
}


Recent research shows that corporate ownership is less concentrated in countries where minority shareholders are better protected against expropriation. La Porta, Lopez-de-Silanes, Shleifer (1999), Djankov, La Porta, Lopez-de-Silanes, and Shleifer (2008), and Dyck and Zingales (2004) find higher incidence of concentrated ownership among large firms in countries where the private benefits of control are high. Claessens, Djankov, and Lang (2000) and Faccio and Lang (2002) document similar patterns across firms in Asia and Europe.

We show that the ownership concentration of newly public firms does not vary with investor protection. Immediately following the initial public offering, ownership tends to be fairly concentrated in both countries that do, and countries that do not, provide strong protection to minority shareholders. Measures of investor protection are strongly associated with more dispersed ownership only in samples of mature public firms or in broad cross-sections of young and old firms.

Why does investor protection matter so much in the full cross-section, and so little for newly public firms? Mechanically, it must be due to differences in the experiences of these firms following IPO. After first listing on the stock market, firms in countries with better institutions become widely held at a faster rate. This is apparent in the contrast between the typical newly listed firm in the US and its counterpart in Brazil. In both countries, block ownership of the median firm is about 50 percent soon after listing. However, in the US, block ownership of the median firm drops to 21 percent within five years, while in Brazil it stays approximately constant.

We assemble new panel data on corporate ownership covering a large panel of firms in 34 countries between 1995 and 2006, including 2,700 firms that go public during this period. Relative to previous studies, the advantage of our data is that we observe blockholdings as well 
as shares outstanding over the early lifespan of these firms as public entities, rather than at a single point in time. This makes it possible to track two conceptually distinct mechanisms underlying ownership dynamics: blockholder sales and issuance of follow-on external equity.

In examining the impact of investor protection, our approach builds on the approach taken by Helwege, Pirinsky and Stulz (2007), henceforth HPS, who explore differences in the evolution of ownership among US listed firms. HPS (2007) find that stock market liquidity has significant effects on the diffusion of ownership - liquid stocks with high past returns tend to become widely held more quickly. However, they do not find evidence that agency problems influence the diffusion of ownership in the US But, as they point out, there is limited variation in such agency problems across firms in their sample. Moreover, as shown by Doidge, Karolyi and Stulz (2007), country characteristics explain more of the variation in firm corporate governance than firm-specific characteristics. Our cross-country panel data therefore offer a suitable setting to study the effects of agency costs on the diffusion of corporate ownership.

We consider two main hypotheses concerning how investor protection affects the evolution of ownership. First, strong investor protection increases the price at which firms can sell shares by reducing the private benefits of control. In Jensen and Meckling (1976), controlling shareholders are reluctant to sell shares because they can only sell them at a price that reflects the resources they are expected to divert. Zingales (1995) and Bebchuck (1999) build on the idea that insiders bear agency costs and explain that controlling shareholders have an incentive to hold onto their shares to protect their private benefits from being expropriated in a takeover or by the actions of a corporate raider. If strong investor protection reduces the extent to which insiders can enjoy private benefits, such protection makes it relatively more attractive for insiders to issue new shares or to sell existing shares to outsiders. While the mechanisms in 
these papers differ, one overall conclusion is that investor protection, by reducing the scope for expropriation of minority investors, increases insiders’ willingness to sell equity. Thus these theories predict a positive association between investor protection and the speed at which firms become widely held.

Refinement of the ideas described above has implications for the interaction of investor protection with growth opportunities. Blockholders trade off the costs of losing control with the potential benefits of new capital. When the benefits of new capital are high - such as when firms face growth opportunities - the benefits of shareholder protection are greater. For firms facing better growth opportunities, the trade off is more likely to favor issuing shares (and thereby diluting ownership) in environments where investor protection limits the scope of agency problems. Put into practice, strong investor protection should interact with growth opportunities to predict diffusion of ownership. And, to the extent that decreases in ownership are driven by the desire to invest, they should primarily be a consequence of share issuance rather than blockholder sales.

While the predictions above concern the dynamics of corporate ownership, they have natural implications for firms’ overall use of leverage and patterns in growth. Faced with growth opportunities, firms in countries with poor protection of minority shareholders may have to rely more heavily on debt to finance growth. Despite substituting toward debt, the findings reviewed in Levine (2005) suggest that firms in countries with weak investor protection are still likely to be constrained in their ability to raise capital. ${ }^{1}$ Put differently, in weak investor protection regimes, we expect firms to substitute towards debt financing, but finance less growth overall.

\footnotetext{
${ }^{1}$ See, for example, Beck, Demirgüç-Kunt and Maksimovic (2005), Beck, Levine and Loayza (2000), Claessens and Laeven (2003), Demirgüç-Kunt and Maksimovic (1998), La Porta, Lopez-de-Silanes, Shleifer and Vishny (1998), Levine (1999), Rajan and Zingales (1998), and Stulz and Williamson (2003).
} 
We find considerable support for the predictions put forth above. Firms in countries with good investor protection become widely held faster, even though ownership is concentrated for a few years around the IPO. Both new share issues and blockholder sales are more common in countries where protection is strong and private benefits of control are small. Investor protection has a particularly pronounced effect on the diffusion of ownership for firms with attractive growth opportunities. Such firms appear to be more willing to issue new shares, thereby diluting ownership. We also find that firms in countries with weak legal protection of shareholders rely more heavily on debt as a source of capital when they face growth opportunities. However, firms’ ability to substitute away from equity to debt appears incomplete. Consistent with other research on finance and growth, we find that firms in countries with weaker investor protection increase investment by smaller amounts than firms in countries with stronger investor protection in response to growth opportunities. To sum up, the results collectively imply that one of the key reasons that ownership concentration falls as firms age is that when investor protection is strong, firms can raise capital and grow. ${ }^{2}$

We consider four alternative hypotheses concerning the diffusion of corporate ownership, each of which could potentially distort the conclusions described above. One alternative explanation is that changes in corporate ownership reflect blockholders' and managers' explicit attempts to time the market. Two thirds of the CFOs surveyed in Graham and Harvey (2001) identify the extent to which equity is “overvalued or undervalued” as an important consideration in the decision to issue external equity. Pagano, Panetta, and Zingales (1998) and Kim and Weisbach (forthcoming) find that firms use only a fraction of the funds they raise for investment, suggesting that market timing plays a role in new issues. In our data, there is some weak

\footnotetext{
${ }^{2}$ Kim (2008) builds on this idea and shows that in countries with strong investor protection, M\&A driven growth is more likely to be equity-based as opposed to cash-based.
} 
evidence that market timing has a direct effect on ownership diffusion. The more salient question, however, is whether market timing conditions were more attractive in countries with strong investor protection, as this type of omitted variable bias would influence our conclusions regarding the effects of investor protection. We do not find any evidence that firms' responsiveness to past returns or to anticipated future returns is related to investor protection.

A second alternative is that measures of investor protection capture effects of stock market liquidity, that is, the ability of blockholders to find a buyer for their shares. Liquidity would have an effect on ownership concentration if insiders would like to sell shares but are reluctant to do so because such sales would put significant pressure on the stock price. ${ }^{3}$ Bhide (1993) suggests that stock market liquidity is one reason why the US has so many widely held firms; Maug (1998) shows that large shareholders should hold smaller stakes when the market is more liquid. HPS (2007) emphasize the role of stock market liquidity in explaining the diffusion of ownership of US firms: stocks with high turnover, for example, tend to become widely held at a faster rate. Griffin, Nardari, and Stulz (2007) show that investors trade more following periods of high returns, so liquidity considerations also predict decreases in ownership concentration following high returns. Consistent with this previous work, we find that proxies for stock market liquidity affect ownership diffusion, but again, these effects appear to be independent of investor protection.

Third, our estimates of the impact of investor protection on ownership diffusion might reflect differences in the types of firms that go public in different environments. Pagano, Panetta, and Zingales (1998) present evidence that Italian firms are larger and older than US

\footnotetext{
${ }^{3}$ Bolton and Von Thadden (1998) point out that liquidity could also facilitate dispersion for reasons related to corporate governance. Greater liquidity could make it easier for takeovers to occur, thus increasing the role of the market for corporate control in ensuring that firms are well run and reducing the need for concentrated owners to exert control.
} 
firms at the time of their IPO. This could imply that firms in countries with weak investor protection require less capital following their IPO, thus reducing the extent to which blockholders are diluted by secondary share issuance. In our data, at the time they go public firms in countries with weak investor protection are larger, more profitable and less R\&D intensive than firms in countries with strong investor protection. Our regression analyses condition on these characteristics, as well as measures of growth opportunities directly. These controls partially address concerns about differences in firm characteristics. Although firms that go public differ in interesting ways across investor protection regimes, these differences do not seem to distort the evidence on the two main hypotheses we test.

A last alternative explanation is that growth opportunities differed across countries during our sample period in a way that is correlated with investor protection. While we measure and control for growth opportunities directly, measurement error could be correlated with country characteristics. Consider the case in which growth opportunities were relatively better than they appear in countries with strong investor protection. In this case, firms in these countries might have stronger incentives to issue equity and become widely held. However, only a small part of the variation in growth opportunities across firms is attributable to cross country differences, and additional tests suggest mismeasurement of growth opportunities not to be an important issue.

The remainder of the paper is organized as follows. The next section describes our data in more detail. Section II presents our main country- and firm-level results. It also contains subsections that consider further implications of our findings and that discuss alternative mechanisms that could explain the diffusion of corporate ownership. The last section concludes.

\section{Data}




\section{A. Investable weight factors}

We rely on a database of "investable weight factors" that is assembled by Standard and

Poors. These data have been collected with the goal of adjusting weights of stocks in their global index products. Most of the major global stock indexes (e.g., S\&P, MSCI, Topix, and FTSE) employ some degree of float weighting in index construction.

The investable weight factor $F$ is

$$
F_{i t}=1-\frac{\sum_{j} B H_{i j t}}{N_{i t}} \text {, }
$$

where $B H$ denotes the number of shares held by blockholder $j$ of firm $i$ and $N$ denotes total shares outstanding. We define the blockholding share as one minus the free float, or

$$
B H S=1-F_{i t}=\frac{\sum_{j} B H_{i j t}}{N_{i t}} .
$$

The underlying blockholder $(\mathrm{BH})$ data are culled from a variety of national sources. Our data account for blocks owned by three types of entities which hold their shares in part because of the benefits of control. These include (1) publicly traded corporations, venture capital firms, private equity firms, and leveraged buy-out groups; (2) government entities; and (3) current or former officers and directors of the company, founders of the company, pension funds, and employee stock ownership plans that are associated with and controlled by the company. Within each group of blockholders, holdings are only considered when they cumulate to over ten percent of shares outstanding. However, individual holdings below five percent of shares outstanding are ignored, except where they belong to clearly related shareholders like family members or board members. The intent of this somewhat arbitrary rule is to attempt to normalize the measure across countries, which have different reporting standards. 
The holdings of mutual funds, insurance companies, and independent foundations are not considered to be a part of blockholdings even if such holdings are large because these owners are not believed to be interested in exerting control. These types of investors are assumed to hold shares solely for purposes of collecting investment returns. While government holdings are in principle part of blockholdings, they tend to be small for the vast majority of firms in our sample. While it is potentially interesting to disaggregate these data to understand the dynamics of ownership among different types of blockholders, our data do not allow it.

Ownership data are at the security level rather than the firm level. As a consequence, we may not accurately measure the extent to which specific owners control firms that have multiple share classes. As a robustness check, we exclude firms for which Datastream reports the existence of more than one share class that is traded in public markets.

Because we are not interested in changes in reported ownership concentration that are related to changes in ownership restrictions, we exclude industries in which these restrictions are prevalent, including airlines, banks, and utilities. This is similar to the practice adopted in HPS (2007), who exclude banks and utilities. ${ }^{4}$

Finally, similar to other studies on ownership concentration, our data do not allow us to track ownership of firms after they are acquired. For example, it may be that some firms become widely held by being acquired by other firms that have dispersed ownership. Notwithstanding this, we can track ownership when a firm issues equity in an acquisition but continues to survive. This appears in our data as an increase in total shares outstanding, and it is a common form of ownership dilution. Kim (2008) analyzes the use of stock- and cash-based mergers across

${ }^{4}$ Some countries impose industry-specific ownership restrictions. Most of these restrictions limit foreign holdings. In the US, for example, foreigners' ownership of airlines is limited to 20 percent. As mentioned above, we exclude airlines, banks, and utilities, among which these restrictions are most prevalent. To address concerns about other instances of ownership restrictions, we have identified firms for which block ownership does not change during the sample period and remains fixed between 50 and 90 percent. These are rare in our data. We have checked that our baseline firm-level regressions in Table $\mathrm{V}$ produce the same results when these firms are removed. 
countries, and he finds that stock-based mergers are more common where investor protection is stronger.

When studying corporate ownership, data integrity is of primary importance. As pointed out by Holderness (forthcoming), conclusions may be sensitive to the sample of firms and to the quality of the underlying data. We have checked the accuracy of our ownership data against other sources. We have matched our data with hand collected data used in Claessens, Djankov, and Lang (2000), Faccio and Lang (2002), Lins (2003), Dlugosz, Fahlenbrach, Gompers, and Metrick (2006), and Holderness (forthcoming). Each of these papers assembles data from a variety of national databases to study the cross-section of ownership in specific countries or regions. With the exception of Dlugosz, Fahlenbrach, Gompers, and Metrick (2006), these datasets measure ownership in a single year, so it is not possible to conduct our tests using them. Nevertheless, these data and our data appear to be similar along measurable dimensions. For firms that appear in our data and the alternative data, the mean blockholder share of ownership is, respectively, $24.9 \%$ and $26.6 \%$. Where the two measures overlap, they are 52 percent correlated. We also merge our ownership data with ownership data drawn from Worldscope. Measures of blockownership from these two sources also have similar means and a correlation of 0.74 .

Despite these checks, we might still expect data limitations to induce measurement error at the firm level. To reduce the potential impact of data errors, we point out that we are interested in changes in ownership concentration. Level differences in the quality of firm-level data should not affect our inferences, and we see no reason that measurement error should be correlated with any of our explanatory variables. Nevertheless, we apply a cautious empirical approach in that we focus on large changes in blockholding. 


\section{B. Dynamics of Corporate Ownership: Some Examples}

To provide some intuition for the process by which firms become widely held, we briefly consider some examples that make evident that the percentage of shares outstanding held by blockholders can change for two reasons: either blockholders buy or sell, or the firm issues or repurchases outside equity.

Our first example, Nihon Eslead, a condominium developer in Japan, is a firm for which the blockholding share decreases following the IPO primarily because of sales from the largest blockholder. The firm initially went public in October 1999, but our coverage begins in December 2000. Panel A of Figure 1 shows the dynamics of the blockholding share for this firm. The thick lighter line shows the number of shares outstanding each year scaled by shares outstanding at the end of December 2000. The thin darker line shows total blockholdings in a particular year scaled by December 2000 shares outstanding. The dashed line (measured on the right axis) shows blockholdings in a particular year expressed as a percentage of shares outstanding in that year. In 2000, the majority of shares were owned by founder Sugio Aramaki. Shares outstanding remain approximately level between 2000 and 2006. Over this period Aramaki and another blockholder sold many of their shares so that blockholdings, expressed as a percentage of shares outstanding, fell from 91\% to 48\%. Data from the Japan Securities Handbook confirm these trends.

Our second example, Carrier Access, traded on NASDAQ, is a firm for which the largest increase in float occurs primarily because of a share issuance. The company first went public in July of 1998, and co-founding spouses Roger Koenig and Nancy Pierce together maintained ownership of approximately half of the company's shares. Between 2003 and 2004, the fraction 
of shares held by blockholders fell from 0.56 to 0.40 because of the issuance of shares in a secondary offering. As shown in Panel B of the figure, this event is the largest change in float during the sample period.

The third panel shows our last example: Increases in float for the German firm Infineon Technologies occur jointly through the issuance of equity due to stock based mergers and acquisition and blockholder sales.

\section{Other data}

In much of the analysis, we limit the sample to firms that can be identified on Worldscope and Datastream, which are also the source of many of the controls in our firm-level regressions. In the tests that follow, we draw data from the full matched database, as well as the subset in which we can track ownership of the firm immediately after IPO. We use the Datastream "base date" to identify firm’s first listing date. ${ }^{5}$ We include new listings for which we have ownership data within 18 months of the listing date. We also require that each country have at least one firm in each country that can be tracked soon after its IPO and that this firm have at least 5 consecutive years of data. This is to ensure that we have a representative sample in each country. The IPO sample (our primary sample) includes 14,087 firm-years, comprising 2,700 unique firms. Table I gives a breakdown of our data by year. Our data cover 34 countries: 23 of these countries are covered from 1995 onwards and the remaining 11 countries from 1998 onwards. With the exception of Argentina, which has only one firm that we can track from IPO,

\footnotetext{
${ }^{5}$ We have checked our sample of IPOs against a sample of IPOs identified in SDC and CRSP, and approximately $82 \%$ of our IPOs appear in these other samples. Results obtained using this more limited sample are not materially different from those presented in the paper.
} 
every other country has at least 6 firms in the IPO sample, and at least 20 firms in the full database. $^{6}$

Worldscope and Datastream provide data used to compute two measures of Tobin's Q. The first of these is firm-specific — the ratio of the sum of the market value of equity and the book value of debt to the book value of assets for each firm in each year. While this measure should reflect opportunities faced by individual firms, it may also reflect a firm’s ability to pursue those opportunities. For example, suppose that investment opportunities in the steel industry are high, reflected in steel firms’ generally high Q. However, if a firm in that industry is unable to exploit those opportunities, its realizable investment opportunities will be low, as will be its Q. Since ideally we would have a measure of Q that is a pure proxy for the investment opportunities faced by the firm, we also compute average Tobin’s Q across all firms in an industry-year. Unlike firm-specific Q, this measure is not contaminated by firms’ ability to pursue growth opportunities.

Additional controls include: the log of assets, the ratio of net property plant and equipment (net PPE) to assets, the ratio of earnings before interest, taxes and depreciation (EBITDA) to sales, the level of research and development (R\&D) expenditures, the ratio of debt to assets. We gather market capitalization from the Standard and Poors data and combine it with split- adjusted stock price data from Datastream to calculate shares outstanding. For US firms, we take shares outstanding directly from the Center for Research in Securities Prices (CRSP).

Our analysis also employs several measures of country characteristics, including two measures of investor protection. The first of these is the Djankov, La Porta, Lopez-de-Silanes, and Shleifer (2008) anti-self-dealing index, which is a composite index of the degree to which a

\footnotetext{
${ }^{6}$ In the original data, there is information on firms in 53 countries. For many of these countries, such as Indonesia, while we have information on blockholdings for a number of firm-years, there are no firms that we can track postIPO. Thus, the final sample of 34 countries is based on data availability.
} 
country’s laws protect minority shareholders against expropriation by corporate insiders. This measure is theoretically grounded, predicts a variety of stock market outcomes, and addresses concerns that have been raised about the antidirector rights index developed in La Porta, Lopezde-Silanes, Shleifer and Vishny (1998). ${ }^{7}$ The second variable is a price-based measure of the private benefits of control. Building on a methodology used by Barclay and Holderness (1989), Dyck and Zingales (2004) measure the average premium that acquirers pay for controlling a block of shares. Last, several of our regression specifications include country measures of market liquidity: Stock market turnover is defined as market-level shares traded scaled by shares outstanding. ${ }^{8}$

Panel A of Table II summarizes the country-level data and Panel B summarizes the data used in the firm-level analysis for the IPO sample. All firm-level scaled variables are winsorized at the $1 \%$ and $99 \%$ level.

\section{Results}

We start by presenting evidence that investor protection operates dynamically by conducting country-level analysis that builds on previous work. We then describe tests of the two main hypotheses relating ownership diffusion to agency costs between minority and majority shareholders and tests of some implications of these hypotheses. The final subsection discusses four alternative hypotheses that could potentially distort our conclusions.

\section{A. Country-level analysis of the dynamic effects of investor protection}

\footnotetext{
${ }^{7}$ A previous version of this paper replicates most of our results using the earlier Antidirector measure.

${ }^{8}$ Stock market turnover data are taken from La Porta, Lopez-de-Silanes, and Shleifer (2006).
} 
We start by testing for a relation between ownership concentration and investor protection at the country level. Existing cross-country studies indicate that ownership concentration is higher in countries with weaker investor protection, but these studies focus primarily on samples of mature firms.

As a benchmark for our subsequent analysis, and to see if these previous results hold in our data, we isolate a sample of firms that have been public for at least 5 years in 2005 and run country level regressions that analyze differences in ownership concentration. These regressions are similar in spirit to those presented in La Porta, Lopez-de-Silanes, and Shleifer (1999), Dyck and Zingales (2004), and other papers.

Panel A of Table III shows the results. The dependent variable is the median blockholding share in each country (the idea is to capture the ownership concentration of the typical firm). The independent variables are: a Low Legal Protection dummy, Stock Market Turnover, and the Log of GDP per Capita. The Low Legal Protection dummy is equal to one if the anti-self-dealing index takes a value less than the median value for the countries in our sample. Stock Market Turnover proxies for market liquidity, and the Log of GDP per Capita controls for general differences in country development.

The Low Legal Protection dummy in the third column attracts a coefficient of 0.109, implying that the ownership concentration of firms that have been publicly listed for at least five years is approximately $11 \%$ higher in countries with weak investor protection as opposed to strong investor protection. Stock Market Turnover attracts a coefficient of -0.082, suggesting an independent effect of market liquidity on ownership concentration. This finding is consistent with the results of the firm-level specifications in HPS (2007). 
Panel B shows similar tests conducted on a sample of firms that have only recently gone public. We rearrange our data into IPO time, and select the first post-IPO year observation for each firm, as long as it is within one year of the firm's IPO. The dependent variable is the median blockholding share for firms in this sample by country. In column 3, the coefficient on the Low Legal Protection dummy is not significant, and it is more than $40 \%$ smaller than the corresponding coefficient in Panel A. In short, there does not appear to be a relation between investor protection and ownership concentration for newly public firms.

To shed light on the contrast between Panel A and Panel B of Table III, Figure 2 plots blockholding shares in IPO time for firms in countries with low and high investor protection. ${ }^{9}$ The distinction between low and high investor protection is again based on the sample median value of the anti-self-dealing index.

Around the time of the IPO, the median blockholding share is similar (and high) in both high and low investor protection countries. Ownership diffuses following IPO in countries with strong investor protection - so that the median blockholding share falls from $60 \%$ to below $25 \%$ after 5 years. In countries with weak investor protection, however, the median blockholding share remains above $45 \%$ five years after firms are public. The figure suggests that previous results on the cross-section of ownership are in large part driven by differences in the evolution of ownership over time.

Taken together, the results indicate that investor protection has an effect that accumulates through time for firms that have recently gone public. We can estimate this effect more formally by running OLS regressions of the change in blockholdings on a set of country characteristics:

\footnotetext{
${ }^{9}$ Figure 2 is created using a dataset formed by merging the S\&P data with Datastream, which allows us to indentify IPOs. This dataset includes information on 3025 IPOs; this is slightly more than the primary sample we analyze below because there is no requirement that firms appear in Worldscope.
} 


$$
-\Delta B H S_{k t}=a+b B H S_{k t-1}+c P_{k}+d \text { Turnover }_{k}+e \log (G D P)_{k}+\varepsilon_{k t}
$$

where $k$ indexes the country and $t$ indexes the year, and $P$ measures investor protection. The dependent variable is a measure of decreases in the median ownership share held by blockholders for firms in the IPO sample. It is the difference between the country median block ownership between two consecutive years and therefore captures the typical change in ownership concentration for newly public firms. Larger values of this dependent variable imply larger decreases in block holding, and negative values are increases in blockholding. This approach facilitates comparison with the firm level analysis that follows. We control for lagged blockholding because large decreases are more common for firms with larger initial levels of blockholding. T-statistics are based on standard errors that are clustered at the country level.

The tests are presented in Table IV and use the same independent variables as before. Although the coefficient on the Low Legal Protection dummy is only marginally significant in the first column, it is significant in the third. The Low Investor Protection dummy attracts a coefficient of -0.026, implying that decreases in median blockholding shares are 2.6 percentage points larger in countries with stronger investor protection. The magnitude of this effect is considerably larger than the one percentage point mean decrease in block holding share observed in the data.

\section{B. Firm-level analysis of the two main hypotheses}

An agency based theory of corporate ownership stresses the tradeoff between the costs of losing control and the benefits of obtaining new capital. A good test of the theory would identify both the costs and the benefits, and thus requires firm-level data. Specifically, firm-level data help isolate the benefits of new capital by measuring firm-level growth opportunities. 
To review, our predictions are as follows. If strong investor protection reduces the cost of losing control, then firms in countries with high protection would be more likely to decrease ownership concentration. The impact of investor protection should interact with growth opportunities. Investor protection should have larger effects for firms with attractive growth opportunities. These firms have stronger incentives to issue equity, thereby diluting ownership.

We first present some aggregate statistics on the incidence of decreases in the blockholding share across types of countries for firms with different growth opportunities. These are shown in Panel A of Figure 3. In the figure, the bars represent the share of firm-years for which there is a greater than five percent decrease in ownership concentration. The left bars show this share for firms in countries with weak investor protection, and the right bars show this share for firms in countries with strong investor protection. Within each pair, the shaded bar shows the share for firms with an above sample median beginning-of-period Tobin's Q, and the clear bar shows the share for firms with below sample median beginning-of-period Tobin's Q. Decreases in the blockholding share occur more often in countries with strong investor protection. Decreases in blockholding shares among firms with poor growth opportunities are similar across countries with low and high investor protection, but decreases are particularly prevalent among firms with strong growth opportunities in countries with high investor protection. More than $40 \%$ of observations in this category are associated with decreases in blockholding shares in excess of $5 \%$.

To analyze these decreases more formally, our main specification modifies the baseline regression in HPS (2007). As in HPS (2007), the dependent variable is a dummy that is equal to one when the blockholding share decreases by at least $5 \%$. This approach keeps the focus on large changes in ownership structure, rather than, for example, small changes that arise when 
managers exercise stock options. It is also appropriate given that hypotheses about the effects of growth opportunities on incentives to raise capital and dilute blockholders primarily have implications for decreases, rather than increases, in ownership concentration. We estimate probit regressions forecasting changes in the blockholding share:

$$
\operatorname{Pr}\left(\left(\Delta B H S_{i j k t}<-0.05\right)=1\right)=a+b B H S_{i j k t-1}+c Q_{i j k t-1}+d P_{k}+e Q_{i j k t-1} \times P_{k}+Z_{t} F+\varepsilon_{i j k t}
$$

where $i, j, k, t$ denote firm, industry, country, and year, $Q$ measures growth opportunities, $P$ measures investor protection, and $Z$ is a vector of controls based on HPS (2007). Each specification includes as a control the blockholder share at the start of the year $\left(B H S_{t-1}\right)$, because firms with a high blockholder share are more likely to experience declines (in the limit, it is not possible for firms that have no blockholders to experience decreases in block ownership). We also include year fixed effects as well as the log of GDP per capita, in an effort to isolate the effects of investor protection as distinct from overall financial development. Standard errors are clustered by country.

Table V shows the results. The 0.029 coefficient on lagged Tobin’s Q in the first column implies that a one standard deviation increase in a firm's investment opportunities from its mean, keeping all other variables at their mean, increases the likelihood of a large drop in the blockholding share by 2.1 percentage points. The negative and significant coefficient on the Low Legal Protection dummy and the positive and significant coefficient on Stock Market Turnover are consistent with our earlier country-level findings. Moving from a low to a high investor protection country increases the probability of a decrease in the blockholding share by 6.9 percentage points. The regression in the first column of Table $\mathrm{V}$ is essentially the firm-level analogue of the regressions in Table IV, subjected to additional controls. 
We next estimate how ownership changes in response to investment opportunities, and how this sensitivity varies across countries. We include in our regression the interaction of lagged Tobin's Q with our investor protection dummy variable. The results appear in the second column. The interaction term is negative and significant. The 0.036 coefficient on lagged Tobin's $\mathrm{Q}$, together with the -0.042 coefficient on the interaction term, imply that decreases in blockholdings occur when growth opportunities are high, but only in countries with strong investor protection. The differences between the first two columns suggest that the effects of being in a country with strong investor protection operate through differences in the way firms respond to growth opportunities.

The next two columns vary the proxy for investor protection. Here we use a dummy variable that is equal to one for countries in which the block premium as measured by Dyck and Zingales (2004) is above the median across countries in our sample. The -0.221 coefficient on this variable in column 3 implies that moving from a country with a high block premium to a country with a low block premium increases the probability of a decrease in the block ownership share by about 7.6 percentage points. Column 4 shows that when we include the interaction of the High Block Premium dummy variable with lagged Tobin's Q, the coefficient is negative and significant. Thus, we get broadly similar results using this other measure of investor protection. In columns 5-8, we replace the firm specific measures of Tobin's Q with an industry measure of Tobin's Q. The results are again similar. ${ }^{10}$

The results in Table V suggest that liquidity has an effect on ownership diffusion that is independent from the effects of shareholder protection. In the first column, Stock Market Turnover attracts a coefficient of 0.172 , implying that a one standard deviation increase in stock

\footnotetext{
${ }^{10}$ Similar results obtain if one uses a broader sample of firms that includes IPOs since 1990 and relaxes the restriction that ownership be measured soon after IPO.
} 
market turnover is associated with a 3.2 percentage point increase in the probability of a drop in the blockholding share. The effects of many of the firm level controls included in Table V resemble those estimated in HPS (2007). Results in both papers indicate that lower asset tangibility (as measured by the ratio of net PPE to assets) and lower levels of internally generated funds (as measured by the ratio of EBITDA to sales) are associated with a greater likelihood of firms becoming widely held. According to both sets of estimates, leverage does not have robust effects on the probability of a decrease in ownership concentration. Our coefficient estimates on $R \& D /$ Assets and the $R \& D$ Dummy variable have the opposite sign of those in HPS (2007), although only the coefficients on the R\&D Dummy are significant. HPS (2007) present mixed results on the effects of size, but the coefficients on lagged log assets are consistently negative in our results. This may reflect that larger firms require larger dollar value changes in ownership to exceed the 5\% decrease in block holding ownership shares used to define the dependent variable.

The control variables serve two purposes. First, they help control for firm-level characteristics, apart from Q, that might affect blockholders’ willingness to sell shares and grow. Second, as discussed in subsection D below, newly public firms in different countries have different characteristics. In our data, at the time they go public, firms in countries with weak investor protection are larger, more profitable and less R\&D intensive than firms in countries with strong investor protection. By including these characteristics on the right-hand-side of the regression, we reduce concerns about the effects of these differences.

What drives changes in the blockholding share? By definition, changes in the blockholding share occur because of changes in shares outstanding, or because of blockholding sales. HPS (2007) decompose the percentage change as follows:

$$
\Delta B H S_{t}=\Delta\left(\frac{B H_{t}}{N_{t}}\right)=\frac{\Delta B H_{t}}{N_{t-1}}-\frac{B H_{t}}{N_{t}} \times \frac{\Delta N_{t}}{N_{t-1}}
$$


Where $B H$ denotes the split adjusted shares held by blockholders, and $N$ denotes shares outstanding. The first term on the right hand side of equation (5) captures changes in the blockholding share coming from blockholder sales. The second term captures the change in the block ownership share coming from share issuance. ${ }^{11}$ The second term is itself composed of two terms: the percentage change in $N$, and a scaling factor that accounts for the fact that the dilution is a linear function of initial blockholdings. For example, in the extreme case where initial blockholdings are zero, changes in shares outstanding are irrelevant for the block ownership share.

Our hypotheses concerning ownership dilution suggest that decreases in ownership concentration that are a response to investment opportunities should involve new share issuance and not just blockholder sales to diffuse owners. Agency considerations predict that firms should raise additional equity to finance growth opportunities in countries where investor protection is strong. With respect to block sales, the predictions are less clear: in countries with good investor protection, blockholders should be willing to sell more overall, but there is no obvious interaction with investment opportunities. Blockholder sales, by themselves, do not raise additional capital.

One straightforward way to study different kinds of decreases in blockholding shares is to sort incidents in which the blockholding share drops by 5 percent or more into two groups: those that are due to blockholder sales, and those that are due to share issuance. We code a dummy variable equal to one if the decrease in blockholding share is greater 5 percent and if the second term on the right-hand-side of equation (5) is positive. Thus, this dummy captures incidents in which a decrease in the blockholding share is at least partially driven by new issuance. We also

\footnotetext{
${ }^{11}$ Share issuance can be due to secondary offerings or stock-based M\&A. See Kim (2008) for details on the incidence of each across countries.
} 
code a dummy variable equal to one if the decrease in blockholding share is greater than five percent and if the second term on the right-hand-side of equation (5) is zero or negative. This variable captures decreases in ownership concentration that are driven by blockholder sales without additional equity issuance. By definition, these two dummy variables add up to the dummy variable analyzed in Panel A of Figure 3 and Table V.

Panels B and C of Figure 3 illustrate the extent to which decreases in the blockholding share can be attributed to new issues or to block sales. We first sort firms into groups based on the level of investor protection in their country of domicile. Within each of these groups, we sort again based on Tobin's Q at the start of the year. Panel B shows the percentage of incidents, within each of the four groups, in which the blockholding share falls in part due to share issuance. Panel C shows the percentage of incidents, within each of the four groups, in which the blockholding share falls due to blockholder sales. Note that the bars in each group in Panels B and $\mathrm{C}$ add to the height of the bars in Panel A.

This decomposition affords several observations: First, decreases in ownership concentration that involve share issuance are more common than decreases that are solely due to block sales. This can be seen by comparing the levels of the bars in Panel B to the levels of the bars in Panel C. Second, Panel B shows that firms with better growth opportunities are more likely to issue shares, and the effect of growth opportunities is larger in countries where investor protection is strong. Third, Panel C shows that decreases in blockholding shares that are a consequence of blockholders selling to diffuse owners do not seem to be much affected by growth opportunities.

More formal analysis is shown in Table VI. We repeat the specification from Table V using different dependent variables; the table only shows the main coefficients of interest. In 
Panel A, the dependent variable measures whether the blockholding share changes as a consequence of share issuance. In the first column, the coefficient on Tobin's Q is positive and significant, and the coefficient on Low Legal Protection is negative and significant. Thus, firms with better investment opportunities, and firms in countries with stronger investor protection, are more likely to experience decreases in the blockholding share as a consequence of new share issuance. The specification in the second column adds Tobin's Q interacted with Low Legal Protection. The coefficient on this term is negative and significant, and the coefficient on Low Legal Protection on its own becomes insignificant. Thus, in countries with strong investor protection, firms are more likely to become widely held because they are issuing equity to pursue growth opportunities. Columns 2 and 3 repeat these tests using our alternative measure of investor protection, and columns 4-8 replace firm specific measures of Tobin’s Q with industry measures. Although the statistical significance is weaker in column 6 , the basic effects remain. The dependent variable used in Panel B is a dummy that is equal to one if the decrease in block holding share is greater than $5 \%$ and driven by block sales alone. The negative coefficients on Low Legal Protection in columns 1 and 5 and High Block Premium in columns 3 and 7 indicate that decreases in the block holding share that are a consequence of blockholders selling to diffuse owners are more common in countries with strong investor protection. However, the results in even-numbered columns indicate that the coefficients on proxies for investor protection interacted with measures of growth opportunities are insignificant. Thus, decreases in the blockholding share that are a consequence of blockholders selling their stakes are more common in countries with strong investor protection, but they do not reflect a response to growth opportunities. 
Although they are not reported in the table, we turn briefly to the control variables, which provide some additional color. Stock Market Turnover influences issuance in all of the regressions in Panel A, but it does not come in significantly in Panel B. When looking only at incidents where blockholders sell without changes in shares outstanding we do not find any relation with past stock returns. The coefficient on leverage is positive and significant in the specifications in Panel A but not in Panel B. This is consistent with the view that firms with high leverage lack access to additional debt and are likely to finance growth with newly issued equity instead.

\section{Implications for financing choices and growth patterns}

When faced with investment opportunities, firms in countries with weak investor protection are reluctant to issue new shares and dilute the control of blockholders. Perhaps these firms rely more heavily on debt financing, allowing blockholders to maintain effective control, while still raising some capital. We consider this possibility here.

We keep the analysis as close in spirit to our baseline specifications. We define the dependent variable as a dummy equal to one if leverage, defined as the ratio of the book value of debt to assets, increases by more than five percentage points. ${ }^{12}$ The regressions that follow use industry measures of Tobin's Q to proxy for growth opportunities and therefore are similar to those in columns 5-8 of Table V.

The results in columns 1 and 3 of Table VII show that increases in leverage are not significantly related to growth opportunities and furthermore appear unrelated to investor protection. When interactions of proxies for weak investor protection and Tobin's Q are included, however, as in columns 2 and 4, the coefficient on this interaction is positive and

\footnotetext{
${ }^{12}$ Similar results obtain if one analyzes continuous measures of leverage increases in a Tobit specification.
} 
significant. Thus, firms in countries with weak investor protection tend to increase leverage more than firms in countries with strong investor protection when growth opportunities are attractive.

A number of papers document a relation between financial development and country-, industry-, and firm-level growth. Levine (2005) surveys this work. Even though we find firms in countries with weak shareholder protection substituting towards debt to finance growth opportunities, this substitution may be incomplete. That is, firms in these countries could raise less financing overall, and invest less. While it is not our intention to reinvent the wheel in the extensive finance and growth literature, we can use our main specification from Table VII to understand the determinants of investment. Investment is measured as the change in net PPE scaled by average net PPE over the year.

Tests explaining investment are shown in Table VIII. Investment is higher for firms in industries with higher Tobin’s Q, and lower for firms in countries with poor investor protection. The negative coefficients on the interactions of measures of investor protection and Tobin's Q in columns 2 and 4 imply that firms in countries with poor investor protection increase investment by less than firms in countries with strong investor protection in response to more attractive investment opportunities. In untabulated regressions, we find nearly identical results for asset growth, a broader measure of total investment. These results are reminiscent of Demirgüç-Kunt and Maksimovic (1998) and Rajan and Zingales (1998). They indicate that the type of firms that are particularly likely to become widely held - those that face attractive growth opportunities and are in countries with strong investor protection-grow.

\section{Alternative hypotheses explaining the diffusion of ownership}


We have focused so far on considering agency based explanations of the tradeoff between maintaining control and obtaining capital. Other explanations could play a role in explaining the diffusion of ownership, and their effects could distort the findings in the previous subsections. Here we consider four such alternatives.

\section{i) $\quad$ Market Timing}

One alternative theory that may explain the dynamics of ownership more generally is market timing. Blockholders and managers might attempt to time the equity market when selling existing shares or when issuing new shares. Consistent with this, our results in Table V confirm that decreases in the blockholding share are more likely following high stock returns. The 0.070 coefficient on lagged firm-level stock returns in the first column of Table V implies that a one standard deviation increase in this variable is associated with a 2.2 percentage point greater likelihood of a decrease in the blockholding share. However, as indicated in the analysis used to create Table VI, past returns operate through decreases in blockholding shares involving new share issues, not sales by blockholders. The coefficient on lagged firm returns is negative and insignificant in explaining decreases in the blockholding share that are a consequence of blockholder sales to diffuse owners. This result casts doubt on market timing explanations, because blockholders stand to gain more from timing the sale of their own shares, compared to the gain from new issues (in which they benefit only if net issuance is very large relative to shares outstanding). We also find that decreases in blockholding shares are not predictive of low future returns (not tabulated). ${ }^{13}$ Taken together, our results suggest that decreases in blockholding shares take place when past returns and current valuations are high, but these

\footnotetext{
${ }^{13}$ We have also conducted tests similar to those in columns 2, 4, 6, and 8 of Table V but included past returns and future returns over a one year horizon as well as these variables interacted with the measures of investor protection. None of these interaction terms is significant, and their inclusion does not have a substantive effect on the interaction of measures of Tobin's Q with investor protection. Therefore, market timing considerations do not appear to be particularly salient in countries with strong or weak investor protection.
} 
decreases do not predict that firm valuations in the marketplace will revert to lower levels. In sum, market timing receives only limited support.

\section{ii) Stock Market Liquidity}

Liquidity would have an effect on ownership concentration if insiders are more willing to sell shares when the price impact of doing so is smaller. When applied to our data, the liquidity theory has a straightforward prediction: decreases in ownership concentration should be more common when the stock trades in a more liquid market. Consistent with this prediction, and consistent with HPS (2007), Table V shows that decreases in blockholding shares are more likely in countries with liquid markets. We also replicate the results in Table V using a firm-level measure of turnover, getting similar results to HPS (2007).

If market liquidity is correlated with investor protection, the coefficient on the interaction terms in Table V could indicate how ownership concentration responds differently to investment opportunities in countries with different levels of liquidity. We address this possibility by including measures of Tobin's Q interacted measures of liquidity in our main tests. The coefficient on this interaction term is insignificant, and its inclusion does not have a material impact on the coefficients on the interactions of Tobin's Q with measures of investor protection except for the coefficient on this interaction term in the test presented in column 6 of Table V which becomes slightly smaller in magnitude and insignificant. Therefore, while liquidity appears to affect the diffusion of ownership, its effects seem independent from the effects of investor protection.

\section{iii) Characteristics at IPO}

Third, the characteristics of firms going public may differ across countries, and these characteristics could affect estimates of the importance of institutions. The consequences of 
selling any shares to diffuse shareholders in countries with weak investor protection might make some firms less likely to go public in such environments. To consider this possibility, Table IX presents mean firm characteristics for firms within a year of first listing, dividing the sample on the basis of the legal protection of investors. The first column displays means for firms in countries with where the legal protection of investors is low, the second column for firms where it is high, and the third column gives the difference and shows whether the difference is statistically significant.

Three firm characteristics appear to differ significantly across the two subsamples. Newly public firms in countries with low legal protection appear to have higher assets, higher ratios of EBITDA to sales, and to be less R\&D intensive (in that they report lower ratios of R\&D to assets and are more likely to report R\&D expenditures). Our regressions control for these characteristics, and the results in Table V suggest that larger, more profitable firms are less likely to experience decreases in blockholder shares. Therefore, the characteristics of newly public firms in countries with weak investor protection do affect the diffusion of ownership, but the effects of size, profitability, R\&D intensiveness and measures of investment opportunities operate independently from measures of investor protection and the interaction of measures of investor protection with measures of investment opportunities.

\section{iv) Country Differences in Growth Opportunities}

Fourth and last, growth opportunities may have differed across countries during our sample period in a way that is correlated with investor protection. The tests presented in Table V directly control for growth opportunities with measures of Tobin's Q, and the results indicate that firms with higher Tobin's Q are more likely to experience decreases in the share of ownership owned by blockholders. Additional analysis indicates that measures of Tobin's Q and 
investor protection pick up independent effects. In specifications that include both of these, dropping either does not much change the coefficient on the other. However, growth opportunities may be mismeasured and could conceivably be relatively better than they appear in countries with strong investor protection. It is possible to see if our estimates of the effect of the interaction of investment opportunities with investor protection are robust to this concern by including country-year fixed effects in the specifications presented in Table V. Tests including these effects indentify the impact of investor protection by comparing, across investor protection regimes, within country differences in the extent to which block ownership falls for firms with different relative levels of growth opportunities. Country differences in growth opportunities are absorbed by the fixed effects. In such specifications (not tabulated), the interaction coefficients are similar in magnitude and significance to those presented in Table V.

\section{Conclusions}

We study how the structure of corporate ownership of a firm evolves following first listing, and how this evolution varies across countries. Ownership concentration of newly public firms is high and does not vary with the level of investor protection. In countries with strong investor protection, firms are more likely to experience decreases in the share of ownership of blockholders. Why? In these countries, firms with attractive growth opportunities are more likely to issue equity, diluting their blockholders in the process. Blockholders are also unconditionally more likely to sell. As a result, firms in environments with poor investor protection grow less, and when they do use external finance to fund growth, they lean more heavily on debt. Alternative explanations for the diffusion of ownership receive some support, but they do not distort conclusions about the role of investor protection. The results indicate important 
connections between ownership concentration and growth and suggest that a dynamic view of corporate ownership is required to fully account for the patterns in the data. Our main observation is that firms become widely held in large part because they grow. 


\section{References}

Barclay, Michael J., and Clifford G. Holderness, 1989, Private benefits from control of public corporations, Journal of Financial Economics 25, 371-395.

Beck, Thorsten, Asli Demirgüç-Kunt, and Vojislav Maksimovic. 2005. Financial and Legal Constraints to Firm Growth: Does Firm Size Matter? Journal of Finance 60, 137-177.

Beck, Thorsten, Ross Levine, and Norman Loayza, 2000, Finance and the sources of growth, Journal of Financial Economics 58, 261-300.

Bebchuk, Lucien, 1999, A rent protection theory of corporate ownership and control, NBER working paper 7203.

Bhide, Amar, 1993, The hidden costs of stock market liquidity, Journal of Financial Economics 34, 31-51.

Bolton, Patrick, and Ernst-Ludwig von Thadden, 1998, Blocks, liquidity, and corporate control, Journal of Finance 53, 1-25.

Claessens, Stijn, Simeon Djankov, and L.H.P. Lang, 2000. The separation of ownership and control in East Asian corporations, Journal of Financial Economics 58, 81-112.

Claessens, Stijn and Luc Laeven. 2003. Financial Development, Property Rights, and Growth. Journal of Finance 58, 2401-2436.

Demirgüç-Kunt, Asli, and Vojislav Maksimovic, 1998, Law, Finance, and Firm Growth, Journal of Finance 53, 2107-2137.

Djankov, Simeon, Rafael La Porta, Florencio Lopez-de-Silanes, and Andrei Shleifer, 2008, The law and economics of self dealing, Journal of Financial Economics 88: 430-465.

Dlugosz, Jennifer, Fahlenbrach, Rüdiger, Gompers, Paul, and Andrew Metrick, 2006, Large Blocks of Stock: Prevalence, Size, and Measurement, Journal of Corporate Finance 12, 594-618.

Doidge, Craig, G. Andrew Karolyi, and René Stulz, 2007, Why do countries matter so much for corporate governance?, Journal of Financial Economics 86, 1-39.

Dyck, Alexander, and Luigi Zingales, 2004, Private benefits of control: an international comparison, Journal of Finance 59, 537-600.

Faccio, Mara, and Larry H.P. Lang, 2002, The ultimate ownership of Western European corporations, Journal of Financial Economics 65, 365-395.

Graham, John R., and Campbell Harvey, 2001, The theory and practice of corporate finance: evidence from the field, Journal of Financial Economics 60, 187-243.

Griffin, John, Frederico Nardari, and René Stulz, 2007, Do Investors Trade More When Stocks 
Have Performed Well? Evidence from 46 Countries, Review of Financial Studies 20, 905-951.

Helwege, Jean, Christo Pirinsky, and Rene M. Stulz, 2007, Why do firms become widely held? An analysis of the dynamics of corporate ownership, Journal of Finance 62, 995-1028.

Holderness, Clifford, forthcoming, The myth of diffuse ownership in the United States, Review of Financial Studies.

Jensen, Michael, and William Meckling, 1976, Theory of the firm: Managerial behavioral, agency costs and ownership structure, Journal of Financial Economics 3, 305-360.

Kim, Woojin and Michael S. Weisbach, forthcoming, Motivations for Public Equity Offers: An International Perspective, Journal of Financial Economics.

La Porta, Rafael, Florencio Lopez-de-Silanes, and Andrei Shleifer, 1999, Corporate ownership around the world, Journal of Finance 54, 471-517.

La Porta, Rafael, Florencio Lopez-de-Silanes, and Andrei Shleifer, 2006, What works in securities laws? Journal of Finance 61, 1-32.

La Porta, Rafael, Florencio Lopez-de-Silanes, Andrei Shleifer and Robert Vishny, 1998, Law and finance, The Journal of Political Economy 106, 1113-1155.

Levine, Ross, 2005, Law, Endowments, and Property Rights, Journal of Economic Perspectives 19(3), 61-88.

Levine, Ross, 1999, Law, finance, and economic growth, Journal of Financial Intermediation 8, 8-35.

Lins, Karl V., 2003, Equity ownership and firm value in emerging markets, Journal of Financial and Quantitative Analysis 38, 159-184.

Maug, Ernst, 1998, Large shareholders as monitors: Is there a tradeoff between liquidity and control? Journal of Finance 53, 65-98.

Pagano, Marco, Fabio Panetta, and Luigi Zingales, 1998, Why do companies go public? An empirical analysis, Journal of Finance 53, 27-64.

Rajan, Raghuram G., and Luigi Zingales, 1998, Financial dependence and growth, American Economic Review 88, 559-586.

Stulz, René, and Rohan Williamson, 2003, Culture, Openness, and Finance, Journal of Financial Economics 70, 313-349.

Zingales, Luigi, 1995, What determines the value of corporate votes?, The Quarterly Journal of Economics 110, 1047-1073. 


\section{Figure 1. Tracing Out the Evolution of Ownership.}

The evolution of shares outstanding, total blockholdings, and the blockholding share for three firms following their IPO. Total shares outstanding (thick lighter line) and total blockholdings (thin darker line) are plotted on the left vertical axis. The blockholding share (dashed line) is plotted on the right axis. On the left axis, both series are scaled by shares outstanding at the IPO. Nihon Eslead (Panel A) is a realestate developer in Japan. Carrier Access (Panel B) manufactures telecommunications equipment. Infineon (Panel C) is a spinoff from German industrial conglomerate Siemens.

Panel A: Nihon Eslead 2000-2006

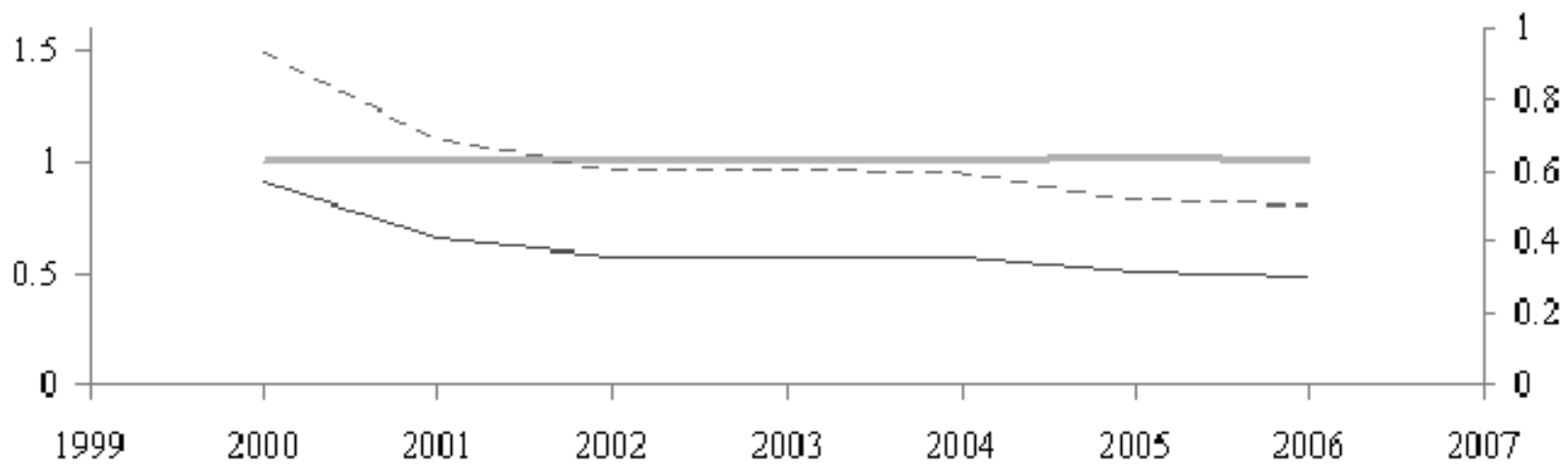

Panel B: Carrier Access 1999-2006

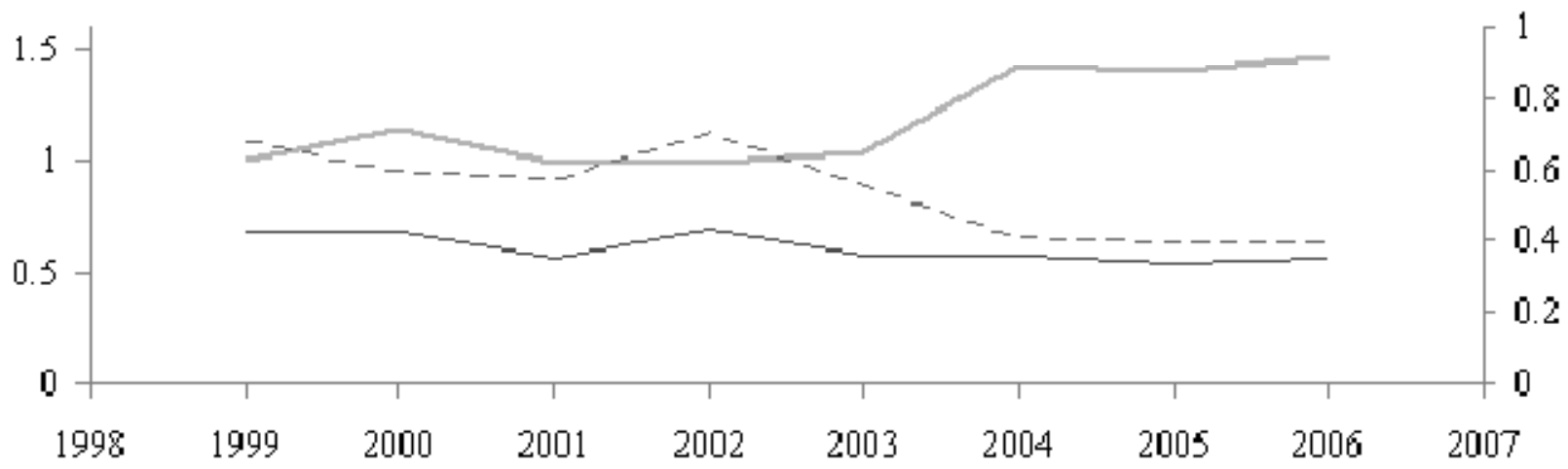

Panel C: Infineon 2000-2006

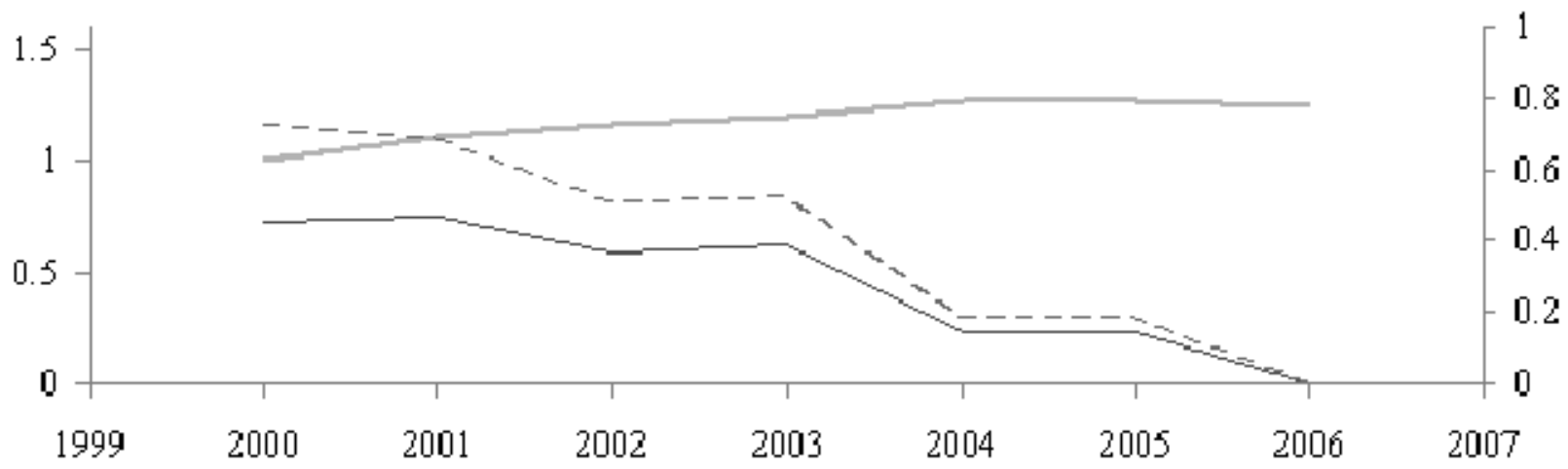


Figure 2. Blockholding Shares and Investor Protection.

Median blockholding share of firms in the IPO sample in years relative to their IPO date. The dashed line indicates median values of blockholding ownership shares for firms in countries where the Djankov, La Porta, Lopez-de-Silanes, and Shleifer (2008) anti-self-dealing index is below its sample median of 0.47 ; the solid line indicates the same measure in countries with an above median anti-self-dealing index score.

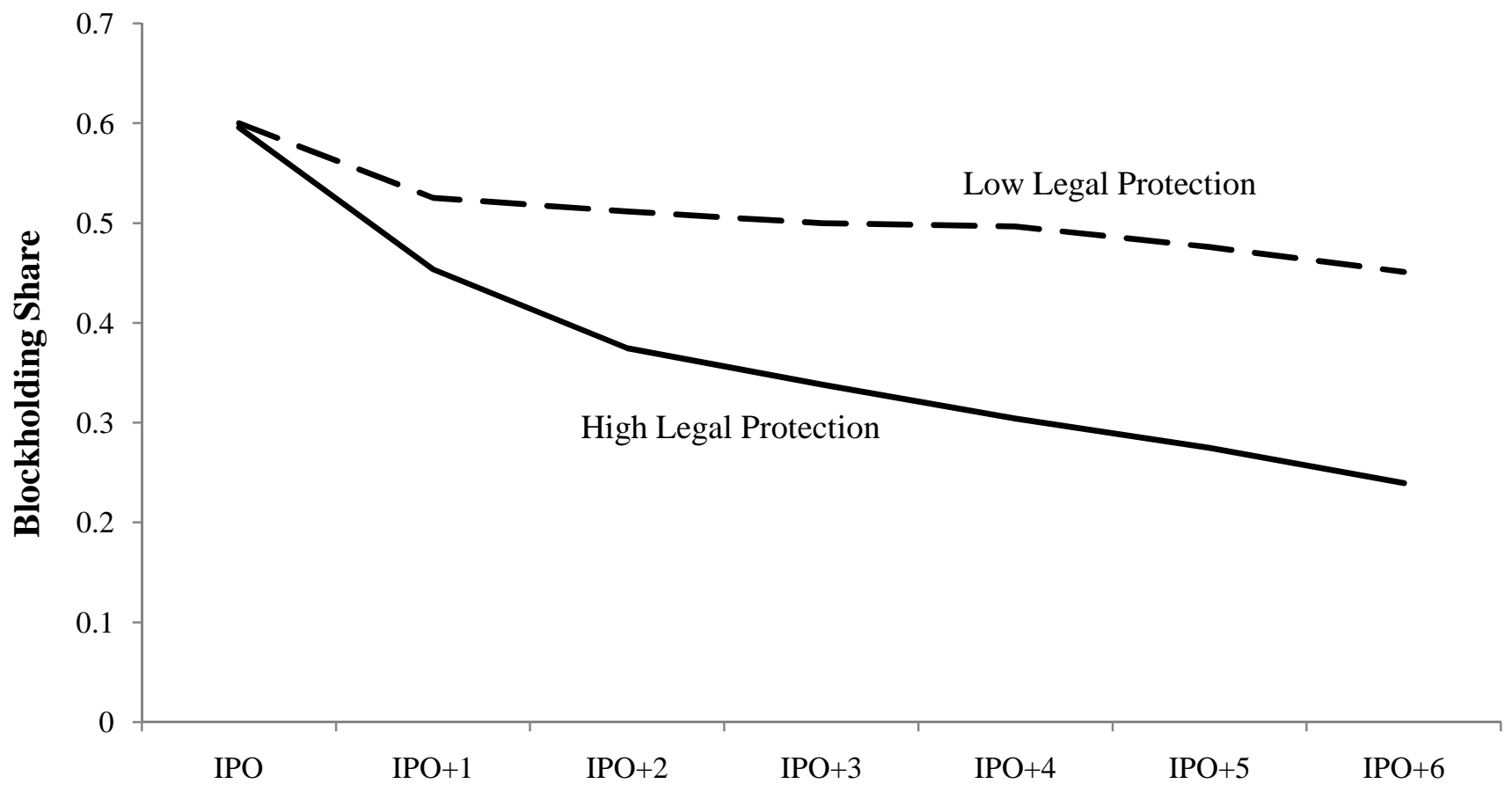


Figure 3. The Incidence of Decreases in Blockholding Shares

The incidence of decreases in blockholding shares that exceed 5\% for firms in different countries that face different growth opportunities. Panel A shows the incidence of all decreases; Panel B shows the incidence of decreases that involve new share issuance; and Panel C shows the incidence of decreases that are solely due to blockholder sales.

Panel A: All decreases in blockholdings

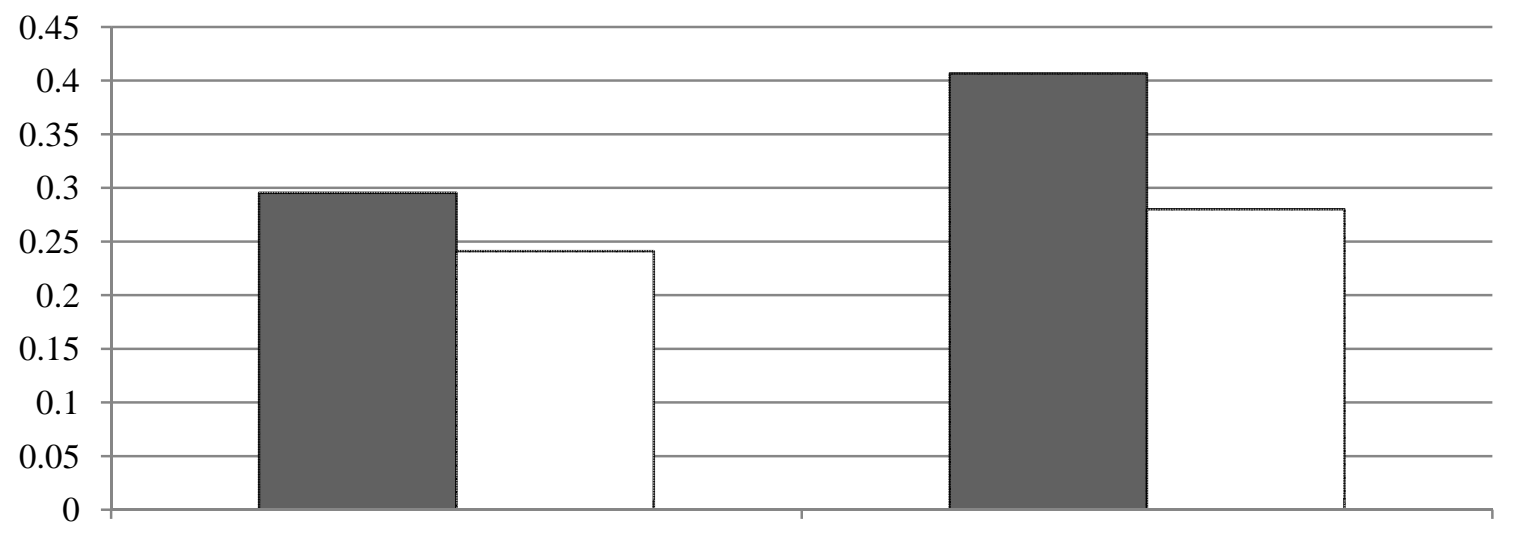

Low Legal Protection

High Legal Protection

Panel B: Decreases in blockholdings involving new share issuance

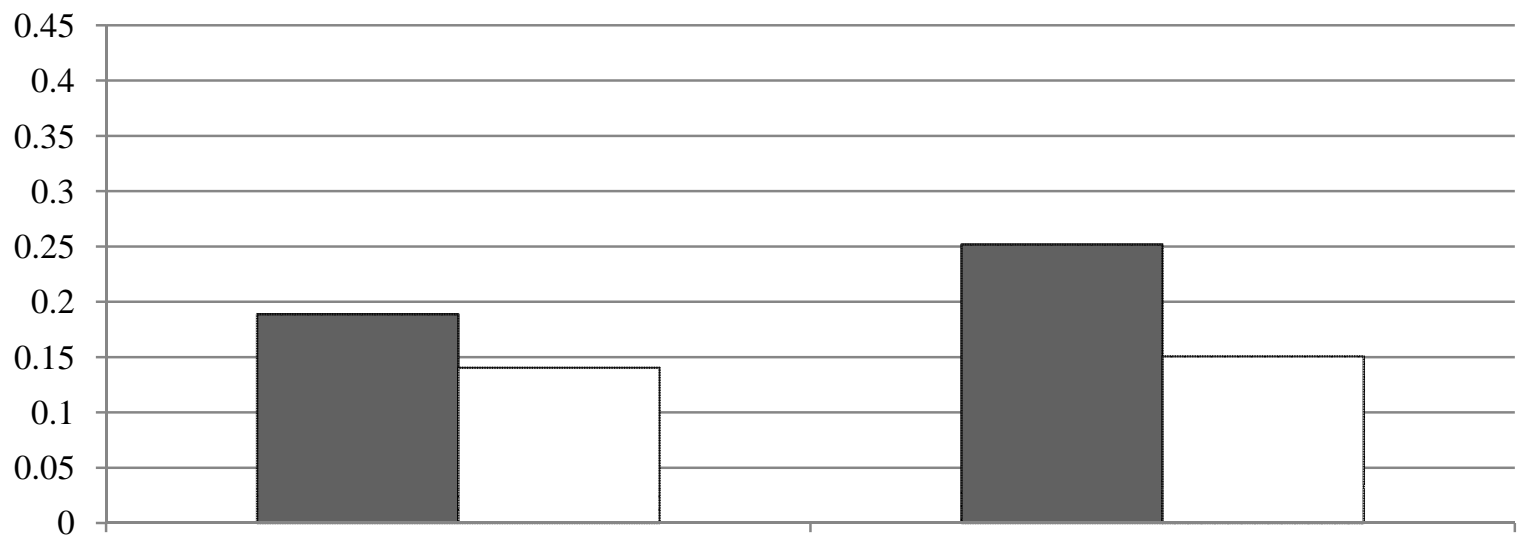

Low Legal Protection

High Legal Protection

Panel C: Decreases in blockholdings resulting from blockholder sales

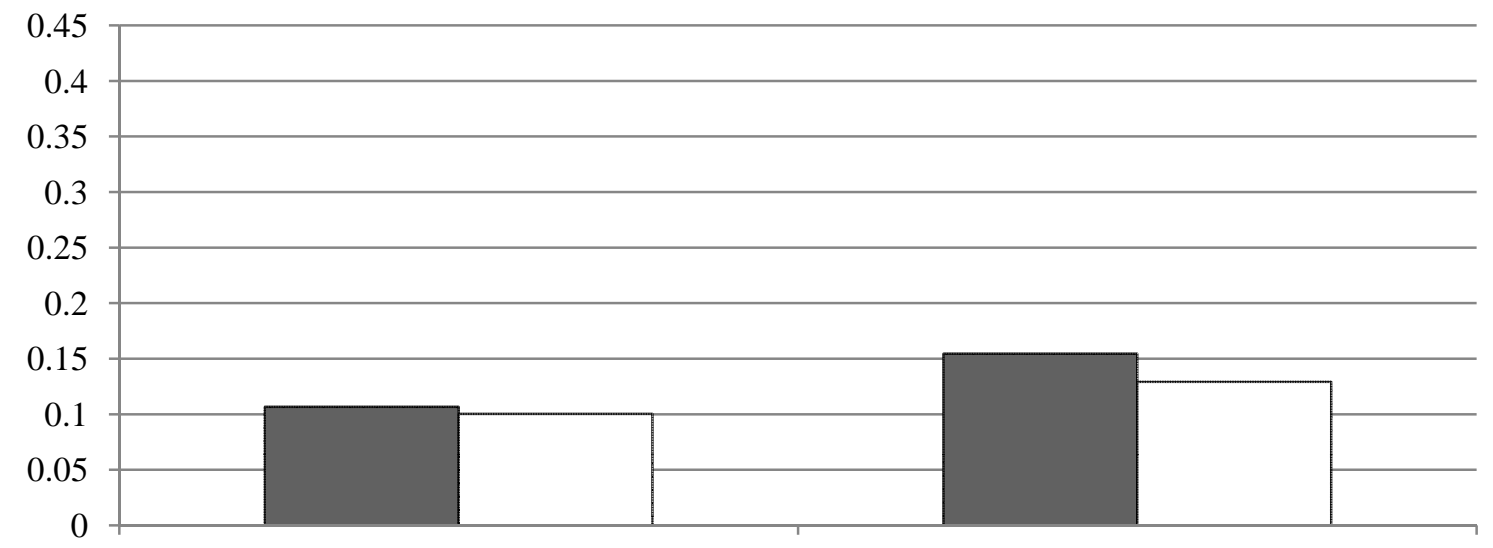

Low Legal Protection

High Legal Protection

口High Growth

Low Growth 


\section{Table I}

\section{Sample Construction}

This table provides information on all firms for which data on the blockholding share are available and which are identified in Worldscope, summarized by year. The table reports the number of countries represented, the number of firm-years, the number of IPOs, and the number of firm-years for the firms in the IPO sample. Because we require at least two consecutive observations of the blockholding share, the sample does not include firms that went public in 2006.

\begin{tabular}{|c|c|c|c|c|}
\hline Year & Countries & Firm-years & Number of IPOs & $\begin{array}{c}\text { IPO Sample: } \\
\text { Firm-years }\end{array}$ \\
\hline 1995 & 23 & 3,385 & 159 & 85 \\
\hline 1996 & 23 & 3,739 & 140 & 215 \\
\hline 1997 & 23 & 4,126 & 205 & 367 \\
\hline 1998 & 34 & 6,343 & 303 & 569 \\
\hline 1999 & 34 & 7,135 & 382 & 787 \\
\hline 2000 & 34 & 7,626 & 459 & 1,136 \\
\hline 2001 & 34 & 7,478 & 238 & 1,462 \\
\hline 2002 & 34 & 7,389 & 177 & 1,629 \\
\hline 2003 & 34 & 7,381 & 107 & 1,752 \\
\hline 2004 & 34 & 7,652 & 208 & 1,866 \\
\hline 2005 & 34 & 8,341 & 322 & 2,079 \\
\hline 2006 & 34 & 7,820 & 0 & 2,140 \\
\hline Total & & 78,415 & 2,700 & 14,087 \\
\hline
\end{tabular}


Table II

\section{Summary Statistics: Country and Firm Level Characteristics}

Panel A shows country characteristics. These include the median blockholding share computed in 2005; the median blockholding share computed within one year of the year the firm went public; the anti-self-dealing index drawn from Djankov, La Porta, Lopez-de-Silanes, and Shleifer (2008); Block Premium, which is the mean block premium measure drawn from Dyck and Zingales (2004); Stock Market Turnover, which measures the total value of stocks traded as a fraction of shares outstanding, is taken from La Porta, Lopez-de-Silanes, and Shleifer (2006); and log of per capita GDP expressed in US dollars. Panel B summarizes dependent variables as well as firm-year characteristics used in the firm-level regressions. The Blockholding Share is the percentage of the firm's equity controlled by blockholders; the Decrease in Blockholding Share Dummy takes a value of one if the blockholding share drops by five percent; $\left(\mathrm{BH} / \mathrm{N}^{*}(\Delta \mathrm{N} / \mathrm{N})\right)>0$ is a dummy equal to one when the drop in the blockholding share involves equity issuance; $\left(\mathrm{BH} / \mathrm{N}^{*}(\Delta \mathrm{N} / \mathrm{N})\right) \leq 0$ is a dummy equal to one when the drop in the blockholding share is due to block sales; the Increase in Leverage Dummy takes a value of one if leverage increases by more than five percent; Change in Net PPE is scaled by average PPE between last year and the current year; Tobin's Q is measured as the ratio of the sum of the market value of equity and the book value of debt to the book value of assets and is lagged and measured at the firm- or industry-year level; stock market returns are measured in local currency terms each year; Net PPE is a firm's net property plant and equipment. EBITDA is a firm's earnings before interest, taxes, and depreciation; R\&D refers to research and development expenditures, and the R\&D dummy is equal to one for firms that report positive levels of R\&D. All scaled variables are winsorized at the $1 \%$ and $99 \%$ levels to remove the influence of outliers.

\begin{tabular}{|c|c|c|c|c|c|c|}
\hline & $\mathrm{N}$ & Mean & Median & $\begin{array}{c}\text { Standard } \\
\text { Deviation }\end{array}$ & Min & Max \\
\hline & \multicolumn{6}{|c|}{ Panel A: Country characteristics } \\
\hline Median Blockholding Share (in 2005) & 34 & 0.38 & 0.39 & 0.20 & 0.00 & 0.76 \\
\hline Median Blockholding Share (following IPO) & 34 & 0.53 & 0.53 & 0.17 & 0.20 & 0.83 \\
\hline Anti-Self-Dealing Index & 34 & 0.54 & 0.47 & 0.25 & 0.17 & 1.00 \\
\hline Block Premium & 31 & 0.11 & 0.04 & 0.15 & -0.04 & 0.65 \\
\hline Stock Market Turnover & 34 & 0.74 & 0.63 & 0.59 & 0.10 & 3.15 \\
\hline \multirow[t]{2}{*}{ Log of GDP per capita } & 34 & 9.53 & 9.95 & 1.02 & 6.37 & 10.60 \\
\hline & \multicolumn{6}{|c|}{ Panel B: Firm Characteristics } \\
\hline \multicolumn{7}{|l|}{ Dependent Variables: } \\
\hline Blockholding Share & 13,392 & 0.35 & 0.34 & 0.26 & 0.00 & 1.00 \\
\hline Decrease in Blockholding Share Dummy & 12,248 & 0.33 & 0.00 & 0.47 & 0.00 & 1.00 \\
\hline$\left(\mathrm{BH} / \mathrm{N}^{*}(\Delta \mathrm{N} / \mathrm{N})\right)>0$ & 12,217 & 0.19 & 0.00 & 0.40 & 0.00 & 1.00 \\
\hline$\left(\mathrm{BH} / \mathrm{N}^{*}(\Delta \mathrm{N} / \mathrm{N})\right) \leq 0$ & 12,217 & 0.13 & 0.00 & 0.34 & 0.00 & 1.00 \\
\hline Increase in Leverage Dummy & 12,452 & 0.18 & 0.00 & 0.38 & 0.00 & 1.00 \\
\hline Change in Net PPE & 12,627 & 0.10 & 0.06 & 0.37 & -2.00 & 2.00 \\
\hline \multicolumn{7}{|l|}{ Controls and RHS Variables: } \\
\hline Firm-specific Tobin's $\mathrm{Q}_{\mathrm{t}-1}$ & 14,087 & 2.22 & 1.46 & 2.07 & 0.08 & 9.90 \\
\hline Industry $\mathrm{Q}_{\mathrm{t}-1}$ & 14,087 & 2.07 & 1.70 & 1.23 & 0.26 & 6.48 \\
\hline Lagged Firm Level Stock Returns & 14,087 & 0.24 & 0.00 & 0.93 & -0.99 & 31.94 \\
\hline Log Assets $_{\mathrm{t}-1}$ & 14,087 & 13.04 & 12.92 & 1.53 & 6.89 & 20.37 \\
\hline Net $\mathrm{PPE}_{\mathrm{t}-1} /$ Assets $_{\mathrm{t}-1}$ & 14,087 & 0.26 & 0.18 & 0.23 & 0.00 & 0.92 \\
\hline EBITDA $_{\mathrm{t}-1} /$ Sales $_{\mathrm{t}-1}$ & 14,087 & -0.05 & 0.14 & 1.00 & -6.09 & 0.92 \\
\hline $\mathrm{R} \& \mathrm{D}_{\mathrm{t}-1} /$ Assets $_{\mathrm{t}-1}$ & 14,087 & 0.04 & 0.00 & 0.07 & 0.00 & 0.35 \\
\hline R\&D Dummy & 14,087 & 0.45 & 0.00 & 0.50 & 0.00 & 1.00 \\
\hline Debt $_{\mathrm{t}-1} /$ Assets $_{\mathrm{t}-1}$ & 14,087 & 0.21 & 0.16 & 0.21 & 0.00 & 0.85 \\
\hline
\end{tabular}




\section{Table III}

\section{Country Characteristics and Blockholdings}

Cross-sectional regressions that explain the country median blockholding share. In Panel A, the dependent variable is the median blockholding share computed in 2005 using data on firms that have been public for at least 5 years. In Panel B, the dependent variable is the median blockholding share computed within one year of first listing date. Low Legal Protection is a dummy equal to one if the Djankov, La Porta, Lopez-de-Silanes, and Shleifer (2008) antiself-dealing index is below its sample median of 0.47 . Stock Market Turnover is the total value of stocks traded as a fraction of shares outstanding. In Panel A, the Log of GDP per Capita is measured in 2005, and in Panel B the Log of GDP per Capita is the mean of the log of gdp per capita across IPO year observations for firms in the sample. Heteroskedasticity consistent t-statistics are shown in parentheses. (***, **,* denote significance at the $1 \%$, $5 \%$, and $10 \%$ levels.)

Panel A: In 2005, for firms that have been public for at least 5 years

\begin{tabular}{lccc}
\hline \multicolumn{1}{c}{ Dependent Variable: } & \multicolumn{2}{c}{ Blockholding Share } & $(3)$ \\
& $(1)$ & $(2)$ & 1.562 \\
Constant & 1.584 & 1.582 & $(9.126)^{* * *}$ \\
& $(9.693)^{* * *}$ & $(9.291)^{* * *}$ & 0.109 \\
Low Legal Protection & 0.098 & & $(2.195)^{* *}$ \\
& $(1.854)^{*}$ & & -0.082 \\
Stock Market Turnover & & -0.071 & $(3.416)^{* * *}$ \\
& & $(2.723)^{* *}$ & -0.124 \\
Log of GDP per Capita & -0.132 & -0.121 & $(6.180)^{* * *}$ \\
No. of Obs. & $(6.847)^{* * *}$ & $(6.305)^{* * *}$ & 34 \\
R-Squared & 34 & 34 & 0.530 \\
\hline
\end{tabular}

Panel B: Immediately following IPO

\begin{tabular}{lccc}
\hline \multicolumn{1}{c}{ Dependent Variable: } & \multicolumn{3}{c}{ Blockholding Share } \\
\hline & $(1)$ & $(2)$ & $(3)$ \\
Constant & 1.236 & 1.238 & 1.227 \\
& $(6.832)^{* * *}$ & $(7.363)^{* * *}$ & $(6.570)^{* * *}$ \\
Low Legal Protections & 0.0562 & & 0.0617 \\
& $(1.050)$ & & $(1.162)$ \\
Stock Market Turnover & & -0.035 & -0.041 \\
& & $(0.790)$ & $(1.169)$ \\
Log of GDP per Capita & -0.078 & -0.072 & -0.074 \\
& $(3.742)^{* * *}$ & $(3.691)^{* * *}$ & $(3.373)^{* * *}$ \\
No. of Obs. & 34 & 34 & 34 \\
R-Squared & 0.237 & 0.223 & 0.256 \\
\hline
\end{tabular}




\section{Table IV}

\section{Country Characteristics and Blockholdings}

The dependent variable is the median decrease in blockholdings, as a percentage of shares outstanding, in each country-year. Low Legal Protection is a dummy equal to one if the Djankov, La Porta, Lopez-de-Silanes, and Shleifer (2008) anti-self-dealing index is below its sample median of 0.47. Stock Market Turnover is the total value of stocks traded as a fraction of shares outstanding. T-statistics based on standard errors that are clustered at the country-level and are shown in parentheses. (***,**,* denote significance at the $1 \%, 5 \%$, and $10 \%$ levels.)

\begin{tabular}{lccc}
\hline \multicolumn{1}{c}{ Dependent Variable: } & \multicolumn{3}{c}{ Decreases in Blockholding Share } \\
\hline & $(1)$ & $(2)$ & $(3)$ \\
Constant & -0.249 & -0.239 & -0.247 \\
& $(3.778)^{* * *}$ & $(3.568)^{* * *}$ & $(3.703)^{* * *}$ \\
Blockholding Share ${ }_{\mathrm{t}-1}$ & 0.196 & 0.163 & 0.174 \\
& $(4.549)^{* * *}$ & $(4.745)^{* * *}$ & $(4.874)^{* * *}$ \\
Low Legal Protection & -0.022 & & -0.026 \\
& $(1.714)^{*}$ & & $(2.255)^{* *}$ \\
Stock Market Turnover & & 0.015 & $(2.738)^{* * *}$ \\
& & $(1.463)$ & 0.019 \\
Log of GDP per Capita & & 0.018 & $(2.990)^{* * *}$ \\
R-Squared & $(3.177)^{* * *}$ & $(2.792)^{* * *}$ & 331 \\
\hline
\end{tabular}




\section{Table V}

\section{Growth Opportunities and Decreases in Blockholding Shares}

Probit specifications explaining decreases in blockholding shares. The dependent variable is a dummy that takes on a value of one when the blockholding share decreases by more than 5 percent. Low Legal Protection is a dummy equal to one if the Djankov, La Porta, Lopez-deSilanes, and Shleifer (2008) anti-self-dealing index is below its sample median. High Block Premium is a dummy equal to one if the block premium, as measured in Dyck and Zingales (2004), exceeds its sample median. In columns 1-4, Tobin's Q is measured as the ratio of the sum of the market value of equity and the book value of debt to the book value of assets, and in columns 5-8, it is measured by taking means of this ratio across all firms in the same industry and year. Stock Market Turnover is the total value of stocks traded as a fraction of shares outstanding. Lagged Firm Level Stock Returns are in local currency terms. Net PPE is a firm's net property plant and equipment. EBITDA is a firm's earnings before interest, taxes, and depreciation. R\&D refers to research and development expenditures, and the R\&D dummy is equal to one for firms that report positive levels of R\&D. Each specification includes year fixed effects. Z-statistics based on standard errors that are clustered at the country-level are shown in parentheses. (***, **,* denote significance at the $1 \%, 5 \%$, and $10 \%$ levels.)

\begin{tabular}{|c|c|c|c|c|c|c|c|c|}
\hline \multirow[t]{3}{*}{ Dependent Variable: } & \multicolumn{8}{|c|}{ Decrease in Blockholding Share Dummy } \\
\hline & \multicolumn{4}{|c|}{ Firm Specific Tobin's Q } & \multicolumn{4}{|c|}{ Industry Q } \\
\hline & (1) & (2) & (3) & (4) & (5) & (6) & (7) & (8) \\
\hline Constant & $\begin{array}{c}-1.950 \\
(2.845)^{* * *}\end{array}$ & $\begin{array}{c}-2.233 \\
(3.490)^{* * *}\end{array}$ & $\begin{array}{c}-1.911 \\
(2.114) * *\end{array}$ & $\begin{array}{c}-1.985 \\
(2.154)^{* *}\end{array}$ & $\begin{array}{c}-2.222 \\
(3.279)^{* * *}\end{array}$ & $\begin{array}{c}-2.253 \\
(3.300)^{* * *}\end{array}$ & $\begin{array}{c}-1.879 \\
(1.972)^{* *}\end{array}$ & $\begin{array}{c}-1.982 \\
(2.040)^{* *}\end{array}$ \\
\hline Blockholding Share $_{\mathrm{t}-1}$ & $\begin{array}{c}1.257 \\
(8.328)^{* * *}\end{array}$ & $\begin{array}{c}1.255 \\
(8.354)^{* * *}\end{array}$ & $\begin{array}{c}1.241 \\
(7.896)^{* * *}\end{array}$ & $\begin{array}{c}1.239 \\
(7.878)^{* * *}\end{array}$ & $\begin{array}{c}1.281 \\
(8.502)^{* * *}\end{array}$ & $\begin{array}{c}1.280 \\
(8.540)^{* * *}\end{array}$ & $\begin{array}{c}1.266 \\
(8.076)^{* * *}\end{array}$ & $\begin{array}{c}1.266 \\
(8.119)^{* * * *}\end{array}$ \\
\hline Tobin's $Q_{t-1}$ & $\begin{array}{c}0.029 \\
(2.729)^{* * *}\end{array}$ & $\begin{array}{c}0.036 \\
(3.974)^{* * *}\end{array}$ & $\begin{array}{c}0.029 \\
(2.832)^{* * *}\end{array}$ & $\begin{array}{c}0.034 \\
(3.684)^{* * *}\end{array}$ & $\begin{array}{c}0.077 \\
(4.117)^{* * *}\end{array}$ & $\begin{array}{c}0.089 \\
(6.433)^{* * *}\end{array}$ & $\begin{array}{c}0.079 \\
(4.331)^{* * *}\end{array}$ & $\begin{array}{c}0.091 \\
(6.845)^{* * *}\end{array}$ \\
\hline Low Legal Protection & $\begin{array}{c}-0.200 \\
(2.983)^{* * *}\end{array}$ & $\begin{array}{l}-0.114 \\
(1.285)\end{array}$ & & & $\begin{array}{c}-0.202 \\
(2.981)^{* * *}\end{array}$ & $\begin{array}{l}-0.095 \\
(0.995)\end{array}$ & & \\
\hline $\begin{array}{l}\text { Low Legal Protection * } \\
\text { Tobin's } \mathrm{Q}_{\mathrm{t}-1}\end{array}$ & & $\begin{array}{c}-0.042 \\
(2.325)^{* *}\end{array}$ & & & & $\begin{array}{c}-0.055 \\
(2.005)^{* *}\end{array}$ & & \\
\hline High Block Premium & & & $\begin{array}{c}-0.221 \\
(2.862)^{* * *}\end{array}$ & $\begin{array}{l}-0.129 \\
(1.295)\end{array}$ & & & $\begin{array}{c}-0.226 \\
(2.771)^{* * *}\end{array}$ & $\begin{array}{l}-0.057 \\
(0.529)\end{array}$ \\
\hline $\begin{array}{l}\text { High Block Premium * } \\
\text { Tobin's } Q_{\mathrm{t}-1}\end{array}$ & & & & $\begin{array}{c}-0.046 \\
(2.619)^{* * *}\end{array}$ & & & & $\begin{array}{c}-0.086 \\
(3.496)^{* * *}\end{array}$ \\
\hline Stock Market Turnover & $\begin{array}{c}0.172 \\
(3.645)^{* * *}\end{array}$ & $\begin{array}{c}0.172 \\
(3.701)^{* * *}\end{array}$ & $\begin{array}{c}0.175 \\
(3.474)^{* * *}\end{array}$ & $\begin{array}{c}0.175 \\
(3.521)^{* * *}\end{array}$ & $\begin{array}{c}0.171 \\
(3.640)^{* * *}\end{array}$ & $\begin{array}{c}0.170 \\
(3.671)^{* * *}\end{array}$ & $\begin{array}{c}0.172 \\
(3.408)^{* * *}\end{array}$ & $\begin{array}{c}0.174 \\
(3.471)^{* * *}\end{array}$ \\
\hline $\begin{array}{l}\text { Lagged Firm Level Stock } \\
\text { Returns }\end{array}$ & $\begin{array}{c}0.070 \\
(5.697)^{* * *}\end{array}$ & $\begin{array}{c}0.070 \\
(5.760)^{* * *}\end{array}$ & $\begin{array}{c}0.068 \\
(5.575)^{* * *}\end{array}$ & $\begin{array}{c}0.068 \\
(5.627)^{* * *}\end{array}$ & $\begin{array}{c}0.077 \\
(6.322)^{* * *}\end{array}$ & $\begin{array}{c}0.077 \\
(6.277)^{* * *}\end{array}$ & $\begin{array}{c}0.074 \\
(5.984)^{* * *}\end{array}$ & $\begin{array}{c}0.074 \\
(5.885)^{* * *}\end{array}$ \\
\hline Log Assets $_{\mathrm{t}-1}$ & $\begin{array}{c}-0.082 \\
(5.790) * * *\end{array}$ & $\begin{array}{c}-0.082 \\
(5.845)^{* * *}\end{array}$ & $\begin{array}{c}-0.085 \\
(5.517)^{* * *}\end{array}$ & $\begin{array}{c}-0.086 \\
(5.572)^{* * *}\end{array}$ & $\begin{array}{c}-0.085 \\
(5.715)^{* * *}\end{array}$ & $\begin{array}{c}-0.086 \\
(5.725)^{* * *}\end{array}$ & $\begin{array}{c}-0.089 \\
(5.571)^{* * *}\end{array}$ & $\begin{array}{c}-0.089 \\
(5.596)^{* * *}\end{array}$ \\
\hline Net $\mathrm{PPE}_{\mathrm{t}-1} /$ Assets $_{\mathrm{t}-1}$ & $\begin{array}{c}-0.137 \\
(2.326)^{* *}\end{array}$ & $\begin{array}{c}-0.138 \\
(2.357)^{* *}\end{array}$ & $\begin{array}{c}-0.145 \\
(2.558)^{* *}\end{array}$ & $\begin{array}{c}-0.145 \\
(2.547)^{* *}\end{array}$ & $\begin{array}{l}-0.103 \\
(1.569)\end{array}$ & $\begin{array}{l}-0.103 \\
(1.595)\end{array}$ & $\begin{array}{c}-0.111 \\
(1.703)^{*}\end{array}$ & $\begin{array}{c}-0.109 \\
(1.686)^{*}\end{array}$ \\
\hline EBITDA $_{t-1} /$ Sales $_{t-1}$ & $\begin{array}{c}-0.042 \\
(3.799)^{* * *}\end{array}$ & $\begin{array}{c}-0.041 \\
(3.655) * * *\end{array}$ & $\begin{array}{c}-0.043 \\
(3.955)^{* * *}\end{array}$ & $\begin{array}{c}-0.042 \\
(3.832)^{* * *}\end{array}$ & $\begin{array}{c}-0.032 \\
(3.254)^{* * *}\end{array}$ & $\begin{array}{c}-0.031 \\
(3.144)^{* * *}\end{array}$ & $\begin{array}{c}-0.032 \\
(3.421)^{* * *}\end{array}$ & $\begin{array}{c}-0.032 \\
(3.358)^{* * *}\end{array}$ \\
\hline$R \& D_{t-1} /$ Assets $_{t-1}$ & $\begin{array}{c}0.021 \\
(0.090)\end{array}$ & $\begin{array}{c}0.016 \\
(0.068)\end{array}$ & $\begin{array}{c}0.001 \\
(0.004)\end{array}$ & $\begin{array}{l}-0.008 \\
(0.035)\end{array}$ & $\begin{array}{c}-0.064 \\
(0.258)\end{array}$ & $\begin{array}{l}-0.079 \\
(0.325)\end{array}$ & $\begin{array}{l}-0.082 \\
(0.344)\end{array}$ & $\begin{array}{l}-0.102 \\
(0.438)\end{array}$ \\
\hline R\&D Dummy ${ }_{t-1}$ & $\begin{array}{c}0.098 \\
(2.188)^{* *}\end{array}$ & $\begin{array}{c}0.094 \\
(2.102)^{* *}\end{array}$ & $\begin{array}{c}0.097 \\
(2.162)^{* *}\end{array}$ & $\begin{array}{c}0.095 \\
(2.098)^{* *}\end{array}$ & $\begin{array}{c}0.079 \\
(1.786)^{*}\end{array}$ & $\begin{array}{c}0.075 \\
(1.685)^{*}\end{array}$ & $\begin{array}{c}0.078 \\
(1.767)^{*}\end{array}$ & $\begin{array}{c}0.074 \\
(1.679)^{*}\end{array}$ \\
\hline Debt $_{t-1} /$ Assets $_{t-1}$ & $\begin{array}{c}0.222 \\
(1.383)\end{array}$ & $\begin{array}{c}0.222 \\
(1.392)\end{array}$ & $\begin{array}{c}0.218 \\
(1.376)\end{array}$ & $\begin{array}{c}0.217 \\
(1.380)\end{array}$ & $\begin{array}{c}0.234 \\
(1.513)\end{array}$ & $\begin{array}{c}0.234 \\
(1.518)\end{array}$ & $\begin{array}{c}0.234 \\
(1.516)\end{array}$ & $\begin{array}{c}0.231 \\
(1.514)\end{array}$ \\
\hline Log of GDP per Capita & $\begin{array}{c}0.187 \\
(3.403)^{* * *}\end{array}$ & $\begin{array}{c}0.190 \\
(3.406)^{* * *}\end{array}$ & $\begin{array}{c}0.188 \\
(2.452)^{* *}\end{array}$ & $\begin{array}{c}0.195 \\
(2.483)^{* *}\end{array}$ & $\begin{array}{c}0.184 \\
(3.250)^{* * *}\end{array}$ & $\begin{array}{c}0.186 \\
(3.236)^{* * *}\end{array}$ & $\begin{array}{c}0.178 \\
(2.248)^{* *}\end{array}$ & $\begin{array}{c}0.187 \\
(2.289)^{* *}\end{array}$ \\
\hline No. of Obs. & 12,248 & 12,248 & 12,023 & 12,023 & 12,330 & 12,330 & 12,100 & 12,100 \\
\hline Log Likelihood & $-7,154$ & $-7,151$ & $-7,026$ & $-7,023$ & $-7,189$ & $-7,187$ & $-7,059$ & $-7,055$ \\
\hline
\end{tabular}




\section{Table VI}

\section{Share Issuance versus Block Sales}

Probit specifications explaining decreases in blockholding shares that are the result of new share issuance and, alternatively, blockholder sales. In Panel A, the dependent variable is a dummy that takes on a value of one when the blockholding share decreases by more than 5 percent, and this decrease is partially a consequence of new share issuance. In Panel B, the dependent variable is equal to one for decreases in bolckholdings that are entirely a consequence of blockholders selling shares. Low Legal Protection is equal to one if the Djankov, La Porta, Lopez-de-Silanes, and Shleifer (2008) anti-self-dealing index is below its sample median. High Block Premium is a dummy equal to one if the Dyck and Zingales (2004) block premium exceeds its sample median. In columns 1-4 of each panel, Tobin's Q is measured as the ratio of the sum of the market value of equity and the book value of debt to the book value of assets, and in columns 5-8, it is the mean of this ratio across all firms in the same industry-year. Stock Market Turnover is the total value of stocks traded as a fraction of shares outstanding. Control variables include Stock Market Turnover, lagged stock returns, the log of lagged assets, the lagged net PPE to assets ratio, the lagged EBITDA to sales ratio, the lagged $R \& D$ to assets ratio, a lagged R\&D dummy, the lagged ratio of debt to assets, the log of GDP per capita, and a constant. Lagged stock returns are in local currency and are measured at the firm level. Net PPE is a firm's net property plant and equipment. EBITDA is a firm's earnings before interest, taxes, and depreciation; R\&D refers to research and development expenditures, and the R\&D dummy is equal to one for firms that report positive levels of R\&D. Each specification includes year fixed effects. Z-statistics based on standard errors that are clustered at the country-level are shown in parentheses. $(* * *, * * *$ denote significance at the $1 \%, 5 \%$, and $10 \%$ levels.)

Panel A: Share Issuance

Dependent Variable: Decrease in Blockholding Share Dummy where $\left(\mathrm{BH} / \mathrm{N}^{*}(\Delta \mathrm{N} / \mathrm{N})\right)>0$ Firm Specific Tobin's Q Industry $\mathrm{Q}$

\begin{tabular}{|c|c|c|c|c|c|c|c|}
\hline & \\
\hline (1) & (2) & (3) & (4) & (5) & (6) & (7) & (8) \\
\hline $\begin{array}{c}1.761 \\
(9.874)^{* * *}\end{array}$ & $\begin{array}{c}1.759 \\
(9.913)^{* * *}\end{array}$ & $\begin{array}{c}1.763 \\
(9.850)^{* * *}\end{array}$ & $\begin{array}{c}1.761 \\
(9.834)^{* * *}\end{array}$ & $\begin{array}{c}1.783 \\
(9.565)^{* * *}\end{array}$ & $\begin{array}{c}1.782 \\
(9.597)^{* * *}\end{array}$ & $\begin{array}{c}1.786 \\
(9.542)^{* * *}\end{array}$ & $\begin{array}{c}1.785 \\
(9.578)^{* * *}\end{array}$ \\
\hline $\begin{array}{c}0.025 \\
(2.746)^{* * *}\end{array}$ & $\begin{array}{c}0.033 \\
(5.617)^{* * *}\end{array}$ & $\begin{array}{c}0.024 \\
(2.713)^{* * *}\end{array}$ & $\begin{array}{c}0.029 \\
(4.134)^{* * *}\end{array}$ & $\begin{array}{c}0.081 \\
(4.839)^{* * *}\end{array}$ & $\begin{array}{c}0.092 \\
(7.548)^{* * *}\end{array}$ & $\begin{array}{c}0.083 \\
(5.077)^{* * *}\end{array}$ & $\begin{array}{c}0.094 \\
(8.337)^{* * *}\end{array}$ \\
\hline \multirow[t]{4}{*}{$\begin{array}{c}-0.143 \\
(2.492)^{* *}\end{array}$} & $\begin{array}{l}-0.032 \\
(0.415)\end{array}$ & & & $\begin{array}{c}-0.142 \\
(2.431)^{* *}\end{array}$ & $\begin{array}{l}-0.043 \\
(0.496)\end{array}$ & & \\
\hline & $\begin{array}{c}-0.052 \\
(3.096)^{* * *}\end{array}$ & & & & $\begin{array}{l}-0.049 \\
(1.552)\end{array}$ & & \\
\hline & & $\begin{array}{c}-0.187 \\
(2.883)^{* * *}\end{array}$ & $\begin{array}{l}-0.078 \\
(0.928)\end{array}$ & & & $\begin{array}{c}-0.187 \\
(2.698)^{* * *}\end{array}$ & $\begin{array}{l}-0.017 \\
(0.194)\end{array}$ \\
\hline & & & $\begin{array}{c}-0.052 \\
(3.326)^{* * *}\end{array}$ & & & & $\begin{array}{c}-0.085 \\
(2.818)^{* * *}\end{array}$ \\
\hline 12,217 & 12,217 & 11,992 & 11,992 & 12,299 & 12,299 & 12,069 & 12,069 \\
\hline$-5,338$ & $-5,334$ & $-5,239$ & $-5,236$ & $-5,359$ & $-5,357$ & $-5,258$ & $-5,255$ \\
\hline
\end{tabular}

Blockholding Share $_{\mathrm{t}-1}$

Tobin's $\mathrm{Q}_{\mathrm{t}-1}$

Low Legal Protection

Low Legal Protection*

Tobin's $\mathrm{Q}_{\mathrm{t}-1}$

High Block Premium

High Block Premium *

Tobin's $\mathrm{Q}_{\mathrm{t}-1}$

No. of Obs.

Log Likelihood

Panel B: Block Sales

Dependent Variable:

Decrease in Blockholding Share Dummy where $\left(\mathrm{BH} / \mathrm{N}^{*}(\Delta \mathrm{N} / \mathrm{N})\right) \leq 0$ Firm Specific Tobin's Q

Industry $\mathrm{Q}$
(1)

$\begin{array}{cc}0.017 & 0.018 \\ (0.218) & (0.221) \\ 0.007 & 0.006 \\ (0.819) & (0.621) \\ -0.126 & -0.142 \\ (2.150)^{* *} & (1.725)^{*} \\ & 0.008 \\ & (0.427)\end{array}$

Tobin's $\mathrm{Q}_{\mathrm{t}-1}$

High Block Premium

High Block Premium *

Tobin's $\mathrm{Q}_{\mathrm{t}-1}$

No. of Obs.

Log Likelihood
(3)

$-0.009$

(0.117)

0.008

(0.864)

$(0.427)$

$-0.115$

$-0.119$

(1.780)*

(1.380)

0.002

$(0.102)$
(6)

0.028

(0.375)

0.019

(1.396)

(1.133)

$-0.130$

$-0.094$

$(2.243)^{* *}$

(1.090)

$-0.019$

(0.853)
(7)

0.003

(0.039)

0.015

(1.144)
(1.351)

(8)

0.003

(0.037)

0.018 


\section{Table VII}

\section{Growth Opportunities and Increases in Leverage}

Probit specifications explaining increases in leverage. The dependent variable is a dummy that takes on a value of one when leverage, defined as the ratio of the book value of debt to the book value of assets, increases by more than 5 percent. Low Legal Protection is a dummy equal to one if the Djankov, La Porta, Lopez-de-Silanes, and Shleifer (2008) anti-self-dealing index is below its sample median. High Block Premium is a dummy equal to one if the block premium, as measured in Dyck and Zingales (2004), exceeds its sample median. Tobin's Q is measured as the ratio of the sum of the market value of equity and the book value of debt to the book value of assets, taking means of this ratio across all firms in the same industry and year. Stock Market Turnover is the total value of stocks traded as a fraction of shares outstanding. Lagged stock returns are in local currency terms and are measured at the firm-level. Net PPE is a firm's net property plant and equipment. EBITDA is a firm's earnings before interest, taxes, and depreciation. $R \& D$ refers to $R \& D$ expenditures, and the $R \& D$ dummy is equal to one for firms that report positive levels of R\&D. Each specification includes year fixed effects. Z-statistics based on standard errors that are clustered at the countrylevel are shown in parentheses. (***, **,* denote significance at the $1 \%, 5 \%$, and $10 \%$ levels.)

\begin{tabular}{|c|c|c|c|c|}
\hline \multirow[t]{2}{*}{ Dependent Variable: } & \multicolumn{4}{|c|}{ Increase in Leverage Dummy } \\
\hline & (1) & (2) & (3) & (4) \\
\hline Constant & $\begin{array}{l}-0.261 \\
(0.473)\end{array}$ & $\begin{array}{l}-0.222 \\
(0.399)\end{array}$ & $\begin{array}{c}0.162 \\
(0.325)\end{array}$ & $\begin{array}{c}0.268 \\
(0.531)\end{array}$ \\
\hline Blockholding Share $_{\mathrm{t}-1}$ & $\begin{array}{c}-0.171 \\
(2.647)^{* * *}\end{array}$ & $\begin{array}{c}-0.170 \\
(2.584)^{* * *}\end{array}$ & $\begin{array}{c}-0.151 \\
(2.651)^{* * *}\end{array}$ & $\begin{array}{c}-0.150 \\
(2.606)^{* * *}\end{array}$ \\
\hline Tobin's $Q_{t-1}$ & $\begin{array}{c}0.010 \\
(1.005)\end{array}$ & $\begin{array}{l}-0.006 \\
(0.486)\end{array}$ & $\begin{array}{c}0.009 \\
(0.966)\end{array}$ & $\begin{array}{l}-0.006 \\
(0.538)\end{array}$ \\
\hline Low Legal Protection & $\begin{array}{c}0.064 \\
(1.374)\end{array}$ & $\begin{array}{l}-0.068 \\
(0.969)\end{array}$ & & \\
\hline $\begin{array}{l}\text { Low Legal Protection * } \\
\text { Tobin's } \mathrm{Q}_{\mathrm{t}-1}\end{array}$ & & $\begin{array}{c}0.067 \\
(2.808)^{* * *}\end{array}$ & & \\
\hline High Block Premium & & & $\begin{array}{c}0.011 \\
(0.189)\end{array}$ & $\begin{array}{c}-0.179 \\
(1.814)^{*}\end{array}$ \\
\hline $\begin{array}{l}\text { High Block Premium * } \\
\text { Tobin's } Q_{t-1}\end{array}$ & & & & $\begin{array}{c}0.096 \\
(3.037)^{* * *}\end{array}$ \\
\hline Stock Market Turnover & $\begin{array}{c}0.097 \\
(1.850)^{*}\end{array}$ & $\begin{array}{c}0.099 \\
(1.972)^{* *}\end{array}$ & $\begin{array}{c}0.091 \\
(2.143)^{* *}\end{array}$ & $\begin{array}{c}0.090 \\
(2.233)^{* *}\end{array}$ \\
\hline Lagged Firm Level Stock Returns & $\begin{array}{l}-0.027 \\
(1.039)\end{array}$ & $\begin{array}{l}-0.028 \\
(1.060)\end{array}$ & $\begin{array}{l}-0.028 \\
(1.070)\end{array}$ & $\begin{array}{l}-0.029 \\
(1.095)\end{array}$ \\
\hline Log Assets t-1 $_{\text {L }}$ & $\begin{array}{l}-0.002 \\
(0.114)\end{array}$ & $\begin{array}{l}-0.001 \\
(0.056)\end{array}$ & $\begin{array}{l}-0.004 \\
(0.196)\end{array}$ & $\begin{array}{l}-0.003 \\
(0.155)\end{array}$ \\
\hline Net $\mathrm{PPE}_{\mathrm{t}-1} /$ Assets $_{\mathrm{t}-1}$ & $\begin{array}{c}0.301 \\
(2.814)^{* * *}\end{array}$ & $\begin{array}{c}0.301 \\
(2.776)^{* * *}\end{array}$ & $\begin{array}{c}0.289 \\
(2.620)^{* * *}\end{array}$ & $\begin{array}{c}0.285 \\
(2.536)^{* *}\end{array}$ \\
\hline EBITDA $_{t-1} /$ Sales $_{t-1}$ & $\begin{array}{c}-0.065 \\
(3.904)^{* * *}\end{array}$ & $\begin{array}{c}-0.066 \\
(4.036)^{* * *}\end{array}$ & $\begin{array}{c}-0.064 \\
(3.783)^{* * *}\end{array}$ & $\begin{array}{c}-0.065 \\
(3.826)^{* * *}\end{array}$ \\
\hline $\mathrm{R} \& \mathrm{D}_{\mathrm{t}-1} /$ Assets $_{\mathrm{t}-1}$ & $\begin{array}{c}-0.592 \\
(1.257)\end{array}$ & $\begin{array}{l}-0.565 \\
(1.233)\end{array}$ & $\begin{array}{l}-0.597 \\
(1.274)\end{array}$ & $\begin{array}{c}-0.562 \\
(1.238)\end{array}$ \\
\hline $\mathrm{R} \& \mathrm{D}$ Dummy $_{\mathrm{t}-1}$ & $\begin{array}{c}-0.181 \\
(4.943)^{* * *}\end{array}$ & $\begin{array}{c}-0.177 \\
(4.790)^{* * *}\end{array}$ & $\begin{array}{c}-0.174 \\
(4.537)^{* * *}\end{array}$ & $\begin{array}{c}-0.170 \\
(4.440)^{* * *}\end{array}$ \\
\hline Debt $_{\mathrm{t}-1} /$ Assets $_{\mathrm{t}-1}$ & $\begin{array}{l}-0.114 \\
(1.161)\end{array}$ & $\begin{array}{l}-0.114 \\
(1.159)\end{array}$ & $\begin{array}{l}-0.112 \\
(1.121)\end{array}$ & $\begin{array}{l}-0.109 \\
(1.091)\end{array}$ \\
\hline Log of GDP per Capita & $\begin{array}{c}-0.048 \\
(0.935)\end{array}$ & $\begin{array}{l}-0.050 \\
(0.970)\end{array}$ & $\begin{array}{c}-0.109 \\
(2.563)^{* *}\end{array}$ & $\begin{array}{c}-0.117 \\
(2.645)^{* * *}\end{array}$ \\
\hline No. of Obs. & 11,055 & 11,055 & 10,861 & 10,861 \\
\hline Log Likelihood & $-5,052$ & $-5,048$ & $-4,972$ & $-4,967$ \\
\hline
\end{tabular}




\section{Table VIII}

\section{Growth Opportunities and Investment}

OLS specifications explaining net capital investment. The dependent variable is the change in net PPE scaled by the average of beginning and end of period values. Net PPE is a firm's net property plant and equipment. Low Legal Protection is a dummy equal to one if the Djankov, La Porta, Lopez-de-Silanes, and Shleifer (2008) anti-self-dealing index is below its sample median. High Block Premium is a dummy equal to one if the mean block premium, as measured in Dyck and Zingales (2004), exceeds its sample median. Tobin's Q is the ratio of the sum of the market value of equity and the book value of debt to the book value of assets, taking means of this ratio across all firms in the same industry and year. Stock Market Turnover is the total value of stocks traded as a fraction of shares outstanding. Lagged Firm Level Stock Returns are in local currency terms. EBITDA is a firm's earnings before interest, taxes, and depreciation. R\&D refers to $R \& D$ expenditures, and the $R \& D$ dummy is equal to one for firms that report positive levels of R\&D. Each specification includes year fixed effects. T-statistics based on standard errors that are clustered at the country-level are shown in parentheses. (***, **,* denote significance at the $1 \%, 5 \%$, and $10 \%$ levels.)

Dependent Variable:

Blockholding Share ${ }_{\mathrm{t}-1}$

Tobin's $\mathrm{Q}_{\mathrm{t}-1}$

Low Legal Protection

Low Legal Protection *

Tobin's $Q_{t-1}$

High Block Premium

High Block Premium *

Tobin's $Q_{\mathrm{t}-1}$

Stock Market Turnover

Lagged Firm Level Stock

Returns

Log Assets $_{\mathrm{t}-1}$

Net PPE $\mathrm{t}_{\mathrm{t}-1} /$ Assets $_{\mathrm{t}-1}$

EBITDA $_{\mathrm{t}-1} /$ Sales $_{\mathrm{t}-1}$

$R \& D_{t-1} /$ Assets $_{t-1}$

R\&D Dummy ${ }_{\mathrm{t}-1}$

Debt $_{\mathrm{t}-1} /$ Assets $_{\mathrm{t}-1}$

Log of GDP per Capita

No. of Obs.

R-Squared
Change in Net PPE

\section{(1)}

0.666

$(6.076)^{* * *}$

0.098

$(3.050)^{* * *}$

0.035

$(5.555) * * *$

$-0.037$

$(4.403)^{* * *}$
(2)

0.647

$(5.742)^{* * *}$

0.098

$(3.083)^{* * *}$

0.042

0.023

(1.354)

$-0.031$

$(3.646)^{* * *}$
$(12.107) * * *$

-0.036
$(3.185)^{* * *}$

0.005

(0.303)

$-0.022$

(2.200)**

0.032

(4.607)***

0.032

$(4.043)^{* * *}$

0.039

0.039
$(6.573) * * *$

(6.517)***

$-0.019$

$(2.981)^{* * *}$

$-0.020$

$(3.052)^{* * *}$

$-0.105$

$(4.280)^{* * *}$

0.028

$(7.767)^{* * *}$

$-0.696$

$(9.471)^{* * *}$

$-0.105$

(4.269)***

0.028

$(7.712)^{* * *}$

$-0.704$

(9.806)***

$-0.009$

(1.253)

$-0.011$

(1.592)

$-0.095$

$(2.682)^{* *}$

$-0.096$

$(2.718)^{* *}$

$-0.025$

$(3.141)^{* * *}$

$-0.024$

(2.903)***

12,308

0.111

12,308

0.033

0.033

$(3.861)^{* * *}$

$(3.722)^{* * *}$

0.040

0.040

$(6.867)^{* * *}$

$(6.819)^{* * *}$

$-0.019$

$-0.019$

(2.875)***

$(2.920)^{* * *}$

$-0.102$

$-0.102$

(3.967)***

$(3.922)^{* * *}$

0.027

0.028

(8.134)***

$(8.150)^{* * *}$

$-0.691$

$-0.696$

(9.151)***

(9.330)***

$-0.007$

$-0.008$

(1.009)

(1.122)

$-0.097$

$-0.097$

$(2.710)^{* *}$

$(2.746)^{* *}$

$-0.019$

$-0.017$

$(2.163)^{* *}$

(1.907)*

12,084

12,084

0.113

0.111 


\section{Table IX}

\section{Differences in Firm Characteristics at Time of IPO}

Mean values of firm characteristics within a year of first listing. The table shows means for firms in countries with Low Legal Protection, High Legal Protection, and the difference. Low Legal Protection is a dummy equal to one if the Djankov, La Porta, Lopez-de-Silanes, and Shleifer (2008) anti-self-dealing index is below its sample median. Tobin's Q is the ratio of the sum of the market value of equity and the book value of debt to the book value of assets. Net PPE is a firm's property plant and equipment. EBITDA is a firm's earnings before interest, taxes, and depreciation. $R \& D$ refers to $R \& D$ expenditures, and the $R \& D$ dummy is equal to one for firms that report positive levels of R\&D. T-statistics for test of the significance of the difference in means based on standard errors that are clustered at the country-level are shown in parentheses. (***, **,* denote significance at the $1 \%, 5 \%$, and $10 \%$ levels.)

\begin{tabular}{lccc}
\hline & $\begin{array}{c}\text { Low Legal Protection } \\
\text { Countries }\end{array}$ & $\begin{array}{c}\text { High Legal Protection } \\
\text { Countries }\end{array}$ & Difference \\
\cline { 2 - 4 } Tobin's Q & 2.388 & 3.077 & -0.688 \\
& & & $(0.393)^{*}$ \\
Log Assets & 13.543 & 13.003 & 0.540 \\
Net PPE/Assets & 0.330 & & $(0.156)^{* * *}$ \\
& & 0.242 & 0.088 \\
EBITDA/Sales & 0.147 & & $(0.065)$ \\
& & -0.283 & 0.430 \\
R\&D/Assets & 0.012 & & $(0.159)^{* *}$ \\
& & 0.033 & -0.021 \\
R\&D Dummy & 0.328 & & $(0.007)^{* * *}$ \\
& & 0.464 & -0.136 \\
Debt/Assets & 0.212 & & $(0.062)^{* *}$ \\
& & 0.204 & 0.008 \\
& & & $(0.024)$ \\
\hline
\end{tabular}

